\title{
The First Synthesis of Some Novel 4-Chloro Chalcone Based Oxime Ethers: An Experimental and Computational Study
}

\author{
Taner ERDOĞAN*1 \\ ${ }^{1}$ Kocaeli University, Kocaeli Vocational School, Department of Chemistry and Chemical Process Technology, \\ 41140, Kocaeli
}

(Alınış / Received: 13.06.2016, Kabul / Accepted: 14.11.2016, Online Yayınlanma / Published Online: 24.11.2016)

\section{Keywords}

Chalcone,

Oxime,

Oxime ether,

DFT calculation,

Computational chemistry

\begin{abstract}
In this study; a series of novel oxime ethers, 3-(4-chlorophenyl)-1phenyl-2-propen-1-one $O$-benzyl oximes, have been synthesized and characterized by several spectroscopic methods. To the best of our knowledge, this is the first synthesis of 3-(4-chlorophenyl)-1-phenyl-2-propen-1-one $O$-benzyl oximes. The study consists of two parts. In the first part, the synthesis and the characterization of the selected compounds have been carried out. In the second part of our study some DFT (Density Functional Theory) calculations have been performed on the synthesized molecules and the obtained results have been compared with the experimental results. In the study; single point energy calculations, geometry optimizations, frequency analysis, NMR spectral analysis, molecular electrostatic potential map calculations, frontier molecular orbital calculations, determination of some global reactivity descriptors and Mulliken atomic charge calculations have been performed. All DFT calculations were carried out at the B3LYP/6-31G(d), B3LYP/6-311G(d,p) and B3LYP/6-311+G(2d,p) level of theories.
\end{abstract}

\section{Bazı Yeni 4-Klor Kalkon Bazlı Oksim Eterlerin İlk Sentezi: Bir Deneysel ve Hesapsal Çalışma}

\section{Anahtar Kelimeler}

Kalkon,

Oksim,

Oksim eter,

DFT hesaplama,

Hesapsal kimya
Özet: Bu çalışmada; bir seri yeni oksim eterler, 3-(4-klorfenil)-1-fenil-2-propen-1on $O$-benzil oksimler, sentezlenmiş ve çeşitli spektroskopik yöntemlerle karakterize edilmiştir. Bildiğimiz kadarıyla bu, 3-(4-klorfenil)-1-fenilprop-2-en-1on $O$-benzil oksimlerin ilk sentezidir. Bu çalışma iki kısımdan oluşmaktadır. Birinci kısımda seçilen bileşiklerin sentezleri ve karakterizasyonları gerçekleştirilmiştir. Çalışmamızın ikinci kısmında ise sentezlenen moleküller üzerinde bazı DFT (Yoğunluk Fonksiyonel Teorisi) hesaplamaları gerçekleştirilmiş ve elde edilen sonuçlar deneysel sonuçlarla karşılaştırılmıştır. Çalış̧mada; tek nokta enerji hesaplamaları, geometri optimizasyonları, frekans analizleri, NMR spektral analizleri, moleküler elektrostatik potansiyel haritası hesaplamaları, sınır moleküler orbital hesaplamaları, bazı global reaktivite tanımlayıcıların belirlenmesi ve Mulliken atomik yük hesaplamaları gerçekleștirilmiștir. Tüm DFT hesaplamaları B3LYP/6-31G(d), B3LYP/6-311G(d,p) ve B3LYP/6-311+G(2d,p) teori düzeylerinde gerçekleștirilmiştir.

\section{Introduction}

Chalcones are important compounds in organic synthesis because of being important precursors of some important organic compounds such as flavonoids and isoflavonoids. Chalcones can be found widespread in natural products [1] and they have broad spectrum of biological activity [2, 3] Recent studies showed that chalcones are promising anticancer [4], antimalarial [5-7], antiinflammatory
[8], antitubercular [9], antihyperglycemic [10] and antimitotic agents. [11]

Oximes and related compounds are of significant interest because of their synthetic values as intermediates in organic synthesis and their industrial importance. [12] Chalcone oximes are also important compounds in organic chemistry. $[13,14]$. 
In this study, some novel 4-chloro chalcone based oxime ethers, 6a-e, were synthesized and characterized. To the best of our knowledge this is the first synthesis of 3-(4-chlorophenyl)-1-phenyl-2propen-1-one $O$-benzyl oximes, 6a-e. In Figure 1, a typical chalcone structure and its oxime and oxime ether forms are represented.

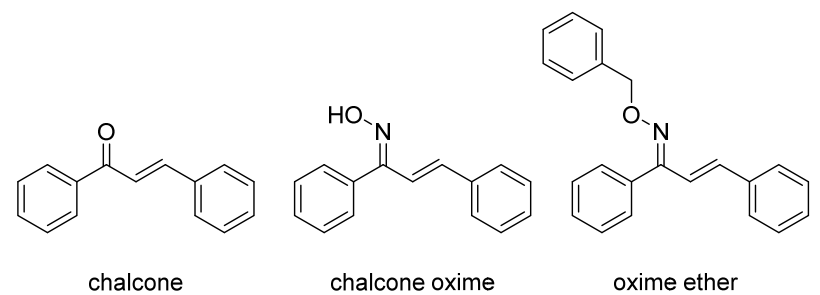

Figure 1. A typical chalcone and its oxime and oxime ether forms.

\section{Material and Method}

\subsection{Experimental}

The literature contains several reports on the synthesis of chalcones from corresponding ketones and aldehydes [2, 15-17] and on the synthesis of chalcone oximes from corresponding chalcones [1821]. The synthetic pathway for the synthesis of novel 3-(4-chlorophenyl)-1-phenyl-2-propen-1-one $O$ benzyl oximes was given in Figure 2.

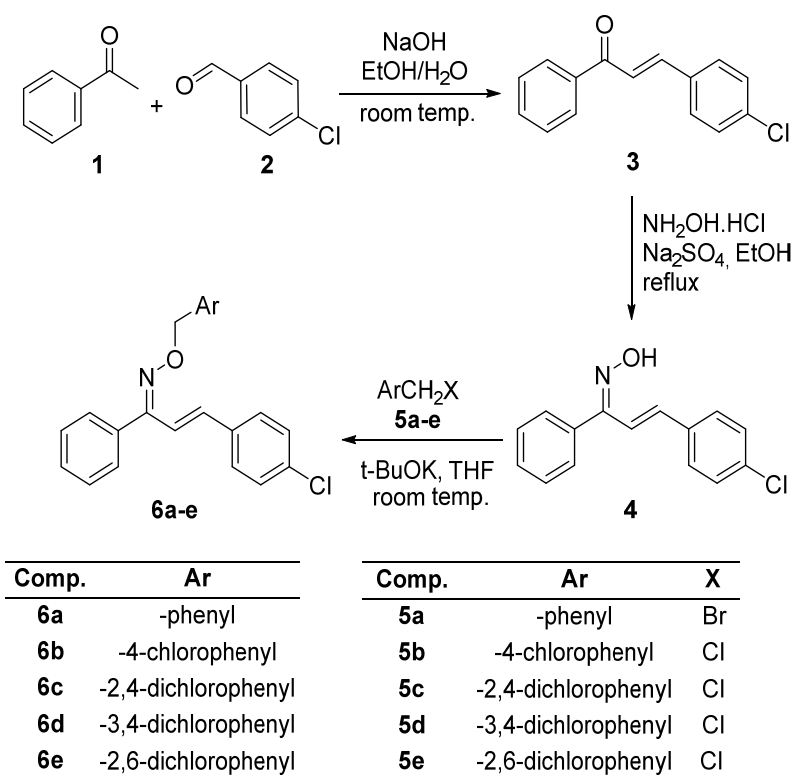

Figure 2. Synthetic pathway.

In the synthesis of chalcone $\mathbf{3}$ from corresponding ketone $\mathbf{1}$ and aldehyde 2, a well known condensation method, Claisen-Schmidt condensation, was used. In the synthesis of oxime 4 , from corresponding ketone 3, hydroxylaminehydrogenchloride and sodium sulfate was used and the reaction carried out at reflux temperature in ethanol. [12] In the synthesis of oxime ethers 6a-e from corresponding oxime $\mathbf{4}$ and aryl halide 5a-e, t-BuOK was used as a base and the reaction was carried out in THF at room temperature.
Procedure for the synthesis of (E)-3-(4-chlorophenyl)1-phenyl-2-propen-1-one, 3

To a solution of acetophenone $(10 \mathrm{mmol})$ in ethanol $(15 \mathrm{~mL})$ and water $(15 \mathrm{~mL}) \mathrm{NaOH}(15 \mathrm{mmol})$ was added portionwise at room temperature with continuous stirring. After 5 minutes, 4chlorobenzaldehyde $(10 \mathrm{mmol})$ was added portionwise in 5 minutes time. After completion of the reaction, the formed solids were filtrated and recrystallized from ethanol.

Synthesis of 3-(4-chlorophenyl)-1-phenyl-2-propen-1one oxime, 4

3-(4-chlorophenyl)-1-phenyl-2-propen-1-one mmol), hydroxylamine hydrochloride $(6 \mathrm{mmol})$ and sodium sulfate ( $4 \mathrm{mmol}$ ) dissolved in ethanol $(25 \mathrm{~mL})$ and refluxed for 5 hours. The reaction mixture was filtrated and the solvent was evaporated under reduced pressure at the end of reflux time. Then water was added, extracted with dichloromethane, dried over anhydrous sodium sulfate and evaporation of the solvent under reduced pressure gave crude product. The crude product was purified by column chromatography on silica gel, eluted with a mixture of Hex:EtOAc (10:1). 3-(4-chlorophenyl)-1-phenyl-2propen-1-one oxime was obtained as a mixture of $(E)$ - and $(Z)$ - isomers (The molar ratio of $E / Z$ isomers is 70:30).

Synthesis of 3-(4-chlorophenyl)-1-phenyl-2-propen-1one 0 -benzyl oximes, 6a-e

To a solution of 3-(4-chlorophenyl)-1-phenyl-2propen-1-one oxime, 4 (2 mmol) in THF $(20 \mathrm{~mL})$, tBuOK (2 mmol) was added portionwise with continuous stirring. After 10 minutes, corresponding benzyl halide $\mathbf{5 a - e}(2 \mathrm{mmol})$ was added portionwise. After 2 hours of stirring at room temperature $5 \mathrm{~mL}$ of methanol was added and the solvent was evaporated under reduced pressure. Then water was added, extracted with dichloromethane, dried over anhydrous sodium sulfate and evaporation of the solvent under reduced pressure gave crude product. The product was purified by column chromatography with a mixture of Hex:EtOAc (10:1).

\subsection{Theoretical calculations}

In the second part of our study we have done some density functional theory (DFT) calculations on the selected molecules 3, 4 and 6a-e and we have made a comparison between experimental and theoretical data. Geometry optimization and frequency analysis were carried out at the DFT B3LYP/6-31G(d), B3LYP/6-311G(d,p) and B3LYP/6-311+G(2d,p) level of theories. NMR calculations were also performed at the same level of theories using both GIAO (GaugeIndependent Atomic Orbital) and CSGT (Continuous Set of Gauge Transformations) models. All theoretical calculations have been performed using Gaussian 09, 
Revision D.01 Program Package [22] and GaussView5 [23] was used for the visualization of the computational results.

\section{Results}

\subsection{Experimental results}

(E)-3-(4-chlorophenyl)-1-phenyl-2-propen-1-one, 3

${ }^{1} \mathrm{H}-\mathrm{NMR}\left(\mathrm{CDCl}_{3}, 300 \mathrm{MHz}\right) \delta 8.03(\mathrm{dd}, \mathrm{J}=8$ and $1.4 \mathrm{~Hz}$, 2H), 7.78 (d, J=16 Hz, 1H), 7.64-7.50 (m, 6H), 7.40 (d, $\mathrm{J}=8 \mathrm{~Hz}, 2 \mathrm{H}) ; \mathrm{m} / \mathrm{z}(\mathrm{ESI}): 243[\mathrm{M}-\mathrm{H}]^{+}$.

3-(4-chlorophenyl)-1-phenyl-2-propen-1-one oxime, 4

1H-NMR $\left(\mathrm{CDCl}_{3}, 300 \mathrm{MHz}\right) \delta 9.30(\mathrm{br}, 2.4 \mathrm{H}), 7.68(\mathrm{~d}$, $\mathrm{J}=16.4 \mathrm{~Hz}, 2.4 \mathrm{H}), 7.56-7.25(\mathrm{~m}, 30.6 \mathrm{H}), 7.07$ (d, J=16.4 $\mathrm{Hz}, 1 \mathrm{H}), 6.78$ (d, 16.4 Hz, 2.4H), 6.46 (d, 16.4 Hz, 1H); $\mathrm{m} / \mathrm{z}(\mathrm{ESI}): 258[\mathrm{M}-\mathrm{H}]^{+}$.

3-(4-chlorophenyl)-1-phenyl-2-propen-1-one O-benzyl oxime, $6 \boldsymbol{a}$

${ }^{1} \mathrm{H}-\mathrm{NMR}\left(\mathrm{CDCl}_{3}, 300 \mathrm{MHz}\right) \delta 7.63(\mathrm{~d}, 3.4 \mathrm{H}, \mathrm{J}=16.6 \mathrm{~Hz})$, 7.55-7.25 (m, 62H), $7.05(\mathrm{~d}, 1 \mathrm{H}, \mathrm{J}=16.6 \mathrm{~Hz}), 6.74(\mathrm{~d}$, $3.4 \mathrm{H}, \mathrm{J}=16.4 \mathrm{~Hz}), 6.40(\mathrm{~d}, 1 \mathrm{H}, \mathrm{J}=16.4 \mathrm{~Hz}), 5.34(\mathrm{~s}$, $6.8 \mathrm{H}), 5.20(\mathrm{~s}, 2 \mathrm{H}) ; \mathrm{m} / \mathrm{z}(\mathrm{ESI}): 348[\mathrm{M}-\mathrm{H}]^{+}$.

3-(4-chlorophenyl)-1-phenyl-2-propen-1-one O-(4chlorobenzyl) oxime, $\mathbf{6 b}$

${ }^{1} \mathrm{H}-\mathrm{NMR}\left(\mathrm{CDCl}_{3}, 300 \mathrm{MHz}\right) \delta$ 7.80-7.15 (m, 55H), 7.02 (d, 1H, J=16.4 Hz), 6.72 (d, 3H, J=16.4 Hz), 6.38 (d, 1H, $\mathrm{J}=16.4 \mathrm{~Hz}), 5.26(\mathrm{~s}, 6 \mathrm{H}), 5.13(\mathrm{~s}, 2 \mathrm{H}) ; \mathrm{m} / \mathrm{z}(\mathrm{ESI}): 382$ $[\mathrm{M}-\mathrm{H}]^{+}$.

3-(4-chlorophenyl)-1-phenyl-2-propen-1-one $\quad 0$-(2,4dichlorobenzyl) oxime, $6 c$

${ }^{1} \mathrm{H}-\mathrm{NMR}\left(\mathrm{CDCl}_{3}, 300 \mathrm{MHz}\right) \delta$ 7.67-7.17 (m, 51H), 7.05 $(\mathrm{d}, 1 \mathrm{H}, \mathrm{J}=16.4 \mathrm{~Hz}), 6.74(\mathrm{~d}, 3 \mathrm{H}, \mathrm{J}=16.4 \mathrm{~Hz}), 6.40(\mathrm{~d}, 1 \mathrm{H}$, $\mathrm{J}=16.4 \mathrm{~Hz}$ ), 5.41 (s, 6H), 5.27 (s, 2H); m/z (ESI): 416 $[\mathrm{M}-\mathrm{H}]^{+}$.

3-(4-chlorophenyl)-1-phenyl-2-propen-1-one $\quad 0$-(3,4dichlorobenzyl) oxime, $\mathbf{6 d}$

${ }^{1} \mathrm{H}-\mathrm{NMR}\left(\mathrm{CDCl}_{3}, 300 \mathrm{MHz}\right) \delta$ 7.65-7.10 (m, 51H), 7.04 $(\mathrm{d}, 1 \mathrm{H}, \mathrm{J}=16.4 \mathrm{~Hz}), 6.73(\mathrm{~d}, 3 \mathrm{H}, \mathrm{J}=16.4 \mathrm{~Hz}), 6.40(\mathrm{~d}, 1 \mathrm{H}$, $\mathrm{J}=16.4 \mathrm{~Hz}$ ), 5.23 (s, 6H), 5.09 (s, 2H); m/z (ESI): 416 $[\mathrm{M}-\mathrm{H}]^{+}$.

3-(4-chlorophenyl)-1-phenyl-2-propen-1-one $\quad 0$-(2,6dichlorobenzyl) oxime, $6 \boldsymbol{e}$

${ }^{1} \mathrm{H}-\mathrm{NMR}\left(\mathrm{CDCl}_{3}, 300 \mathrm{MHz}\right) \delta, 7.65-7.14(\mathrm{~m}, 43.2 \mathrm{H})$, 7.02 (d, 1H, J=16.4 Hz), 6.72 (d, 2.4H, J=16.4 Hz), 6.40 (d, 1H, J=16.4 Hz), 5.58 (s, 4.8H), 5.43 (s, 2H); m/z (ESI): $416[\mathrm{M}-\mathrm{H}]^{+}$.

\subsection{Computational results}

Single Point Energies for Optimized Structures

Single point energies of the compounds 3,4 and 6a-e were calculated at the DFT B3LYP/6-31G(d), B3LYP/6-311G(d,p) and B3LYP/6-311+G(2d,p) level of theories and single point energies for compounds 3 and 4 were given in Table 1.

Table 1. Calculated energies for the $(E)$ - and $(Z)$-isomers of compound 3 and 4.

\begin{tabular}{cccc}
\hline Comp. & $6-31 \mathrm{G}(\mathrm{d})$ & $6-311 \mathrm{G}(\mathrm{d}, \mathrm{p})$ & $6-311+\mathrm{G}(2 \mathrm{~d}, \mathrm{p})$ \\
\hline$(\mathrm{E})-3$ & -30068.109103 & -30073.171799 & -30073.949982 \\
$(\mathrm{Z})-3$ & -30067.923036 & -30072.985377 & -30073.745275 \\
$\Delta \mathrm{E}$ & 0.186067 & 0.186422 & 0.204707 \\
$(\mathrm{E})-4$ & -31561.029634 & -31566.614994 & -31567.520975 \\
$(\mathrm{Z})-4$ & -31560.990671 & -31566.583433 & -31567.502759 \\
$\Delta \mathrm{E}$ & 0.038962 & 0.031561 & 0.018216 \\
\hline
\end{tabular}

Optimized Structure Analysis

Geometric parameters such as bond lengths, bond angles and dihedral angles were determined theoretically at the same level of theories. The calculated molecular structures and molecular parameters of compounds $3,(E)-4,(Z)-4,(E)-6$ a and $(Z)-6 \mathrm{a}$ at the B3LYP/6-311+G(2d,p) level of theory were given in Appendices.

\section{Frequency Analysis}

Frequency analysis for the compounds 3, 4 and 6a-e were carried out at the same level of theories. As an example calculated IR spectra for compound 6a was given in Figure 3.

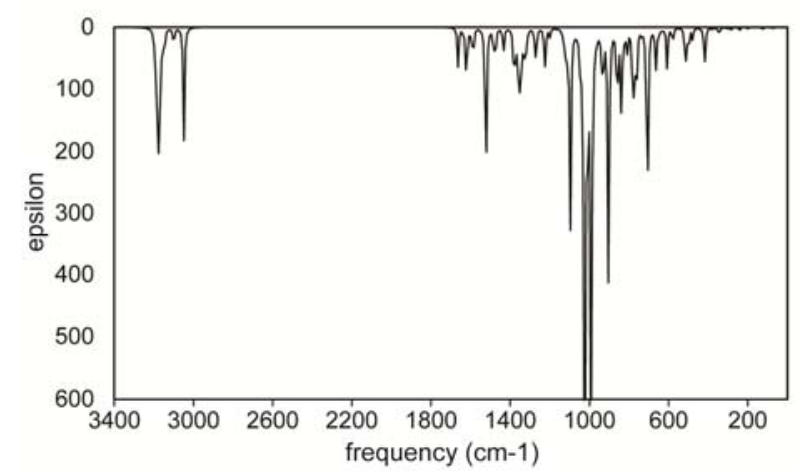

Figure 3. Calculated IR spectra for the compound $6 a$.

NMR Spectral Analysis

Nuclear magnetic shield tensors were computationally determined at the same level of theories using both GIAO (Gauge-Independent Atomic Orbital) and CSGT (Continuous Set of Gauge Transformations) models. Calculated and experimental ${ }^{1} \mathrm{H}-\mathrm{NMR}$ chemical shifts for compounds $(E)-6 \mathrm{a}$ and $(Z)-6 a$ were given in Table 2 and Table 3, respectively. 
Table 2. Experimental and Calculated ${ }^{1} \mathrm{H}-\mathrm{NMR}$ Chemical Shifts for Compound $(E)-6$ a.

\begin{tabular}{cccccccc}
\hline Atom & Exp. & G1 & G2 & G3 & C1 & C2 & C3 \\
\hline 26-H & 7.63 & 7.36 & 7.85 & 8.00 & 4.27 & 6.24 & 7.54 \\
27-H & $7.55-7.25$ & 7.44 & 7.69 & 7.75 & 4.73 & 6.42 & 7.40 \\
28-H & $7.55-7.25$ & 7.25 & 7.55 & 7.64 & 4.69 & 6.34 & 7.30 \\
29-H & $7.55-7.25$ & 7.27 & 7.57 & 7.67 & 4.71 & 6.34 & 7.33 \\
30-H & $7.55-7.25$ & 7.25 & 7.55 & 7.64 & 4.69 & 6.34 & 7.30 \\
31-H & $7.55-7.25$ & 7.44 & 7.69 & 7.75 & 4.73 & 6.42 & 7.40 \\
32-H & 6.74 & 6.29 & 6.62 & 6.78 & 3.54 & 5.33 & 6.41 \\
33-H & $7.55-7.25$ & 7.12 & 7.44 & 7.61 & 4.24 & 5.96 & 7.20 \\
34-H & $7.55-7.25$ & 6.99 & 7.31 & 7.51 & 3.79 & 5.64 & 7.00 \\
35-H & $7.55-7.25$ & 6.99 & 7.31 & 7.51 & 3.79 & 5.64 & 7.00 \\
36-H & $7.55-7.25$ & 7.12 & 7.44 & 7.61 & 4.24 & 5.96 & 7.20 \\
37-H & 5.34 & 5.12 & 5.27 & 5.33 & 3.09 & 4.13 & 5.06 \\
38-H & 5.34 & 5.12 & 5.27 & 5.33 & 3.09 & 4.13 & 5.06 \\
39-H & $7.55-7.25$ & 7.35 & 7.66 & 7.75 & 4.74 & 6.42 & 7.43 \\
40-H & $7.55-7.25$ & 7.17 & 7.46 & 7.56 & 4.66 & 6.28 & 7.22 \\
41-H & $7.55-7.25$ & 7.17 & 7.46 & 7.57 & 4.66 & 6.28 & 7.23 \\
42-H & $7.55-7.25$ & 7.17 & 7.46 & 7.56 & 4.66 & 6.28 & 7.22 \\
43-H & $7.55-7.25$ & 7.35 & 7.66 & 7.75 & 4.74 & 6.42 & 7.43 \\
\hline Exp.: Experimental & & & & & & \\
G1: GIAO 6-31G(d) & & & & & & \\
G2: GIAO 6-311G(d,p) & & & & & \\
G3: GIAO 6-311+G(2d,p) & & & & & \\
C1: CSGT 6-31G(d) & & & & & \\
C2: CSGT 6-311G(d,p) & & & & & \\
C3: CSGT 6-311+G(2d,p) & & & & & & \\
\hline
\end{tabular}

Table 3. Experimental and Calculated ${ }^{1} \mathrm{H}-\mathrm{NMR}$ Chemical Shifts for Compound (Z)-6a.

\begin{tabular}{cccccccc}
\hline Atom & Exp. & G1 & G2 & G3 & C1 & C2 & C3 \\
\hline 26-H & $7.55-7.25$ & 7.14 & 7.44 & 7.56 & 4.63 & 6.26 & 7.19 \\
27-H & $7.55-7.25$ & 7.14 & 7.43 & 7.52 & 4.63 & 6.23 & 7.20 \\
28-H & $7.55-7.25$ & 7.14 & 7.44 & 7.56 & 4.63 & 6.26 & 7.19 \\
29-H & $7.55-7.25$ & 7.32 & 7.57 & 7.68 & 4.69 & 6.39 & 7.26 \\
30-H & $7.55-7.25$ & 7.32 & 7.57 & 7.68 & 4.69 & 6.39 & 7.26 \\
31-H & 6.40 & 6.36 & 6.69 & 6.82 & 3.36 & 5.28 & 6.44 \\
32-H & 7.05 & 7.16 & 7.58 & 7.65 & 4.13 & 5.96 & 7.33 \\
33-H & 5.20 & 4.97 & 5.11 & 5.13 & 2.94 & 3.97 & 4.90 \\
34-H & 5.20 & 4.97 & 5.11 & 5.13 & 2.94 & 3.97 & 4.90 \\
35-H & $7.55-7.25$ & 7.20 & 7.53 & 7.72 & 4.27 & 6.02 & 7.30 \\
36-H & $7.55-7.25$ & 7.02 & 7.36 & 7.51 & 3.80 & 5.65 & 7.05 \\
37-H & $7.55-7.25$ & 7.02 & 7.36 & 7.51 & 3.80 & 5.65 & 7.05 \\
38-H & $7.55-7.25$ & 7.20 & 7.53 & 7.72 & 4.27 & 6.02 & 7.30 \\
39-H & $7.55-7.25$ & 7.47 & 7.79 & 7.86 & 4.85 & 6.54 & 7.54 \\
40-H & $7.55-7.25$ & 7.27 & 7.56 & 7.64 & 4.74 & 6.37 & 7.32 \\
41-H & $7.55-7.25$ & 7.23 & 7.54 & 7.66 & 4.72 & 6.34 & 7.31 \\
42-H & $7.55-7.25$ & 7.27 & 7.56 & 7.64 & 4.74 & 6.37 & 7.32 \\
43-H & $7.55-7.25$ & 7.47 & 7.79 & 7.86 & 4.85 & 6.54 & 7.54 \\
\hline Exp.: Experimental & & & & & & \\
G1: GIAO 6-31G(d) & & & & & \\
G2: GIAO 6-311G(d,p) & & & & & \\
G3: GIAO 6-311+G(2d,p) & & & & & \\
C1: CSGT 6-31G(d) & & & & & \\
C2: CSGT 6-311G(d,p) & & & & & \\
C3: CSGT 6-311+G(2d,p) & & & & & & \\
\hline
\end{tabular}

\section{Molecular Electrostratic Potential Maps}

Molecular electrostatic potential maps provides information about the electron rich and electron deficient parts of the investigated molecule. Molecular electrostatic potential maps were calculated at the same leve of theories. Calculated MEP diagrams for compound 3, (E)-4, (Z)-4, (E)-6a and $(Z)-6 a$ at the B3LYP/6-311+G(2d,p) level of theory were given in Figure $4,5,6,7$ and 8 , respectively.

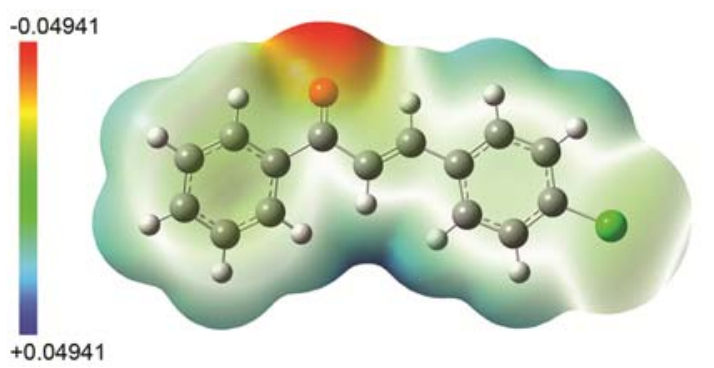

Figure 4. Calculated MEP map for compound 3.

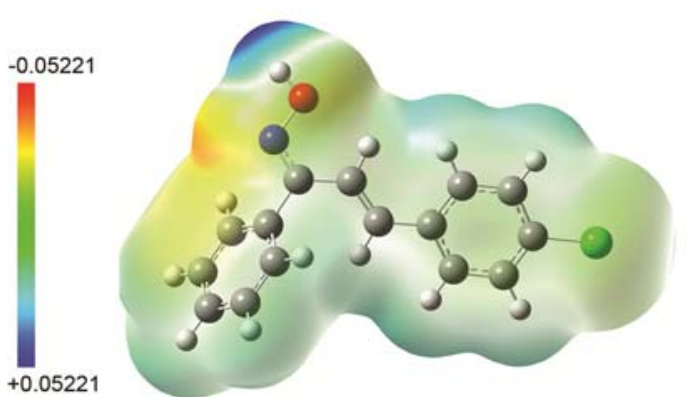

Figure 5. Calculated MEP map for compound (E)-4.

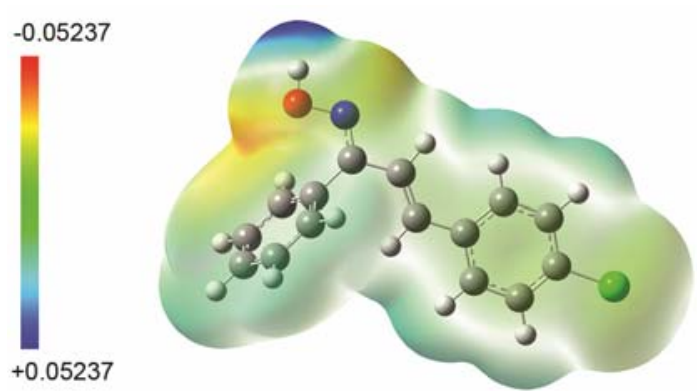

Figure 6. Calculated MEP map for compound (Z)-4.
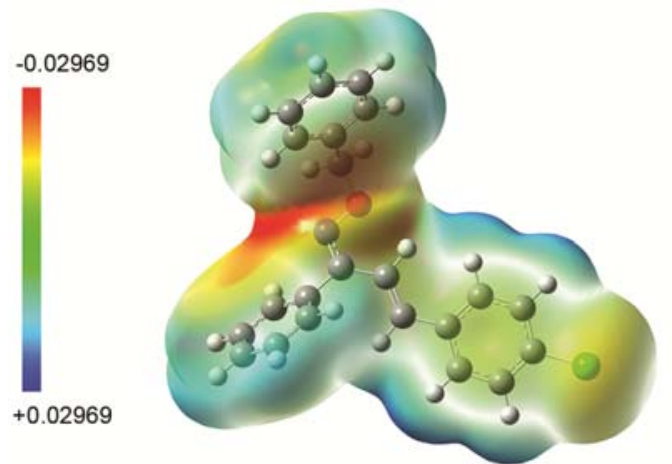

Figure 7. Calculated MEP map for compound (E)-6a.

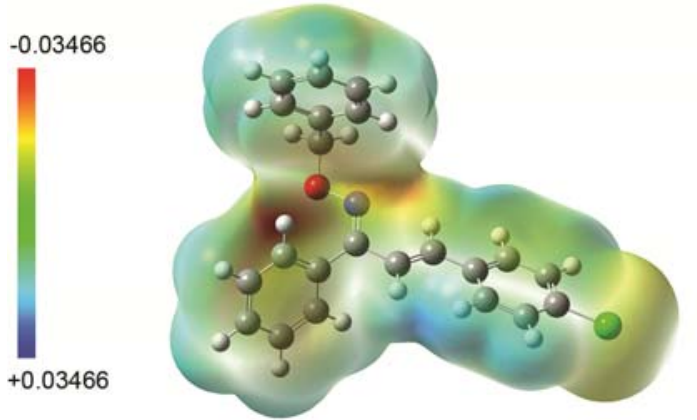

Figure 8. Calculated MEP map for compound (Z)-6a. 
Frontier molecular orbitals and global reactivity descriptors

LUMO and HOMO calculations were carried out at the same level of theories. HOMO and LUMOs of compound 3, $(E)-4,(Z)-4,(E)-6 \mathrm{a}$ and $(Z)-6 \mathrm{a}$ at the B3LYP/6-311+G(2d,p) level of theory were given in Figure 9, 10, 11, 12 and 13, respectively.

Ionization potential $(I)$, electron affinity $(A)$, electronegativity $(\chi)$, chemical hardness $(\eta)$, chemical softness $(S)$, electronic potential $(\mu)$ and electrophilicity index $(\omega)$ values were determined and given for the compounds $3,(E)-4,(Z)-4,(E)-6$ a and $(Z)-6$ a in Table 4.

Ionization potential is the minimum energy required to remove an electron from an atom or molecule and can be calculated with Eq. (1) and electron affinity is the amount of energy released when an electron is added to a neutral atom or molecule in the gaseous state and can be calculated with Eq. (2). [24]

$$
\begin{aligned}
& I=-E_{\text {номо }} \\
& A=-E_{\text {LUMO }}
\end{aligned}
$$

Electronegativity, chemical hardness, chemical softness, electronic chemical potential and electrophilic index can be calculated with Eq.(3)Eq.(7). [24-31]

$$
\begin{gathered}
\chi=(I+A) / 2 \\
\eta=(I-A) / 2 \\
S=1 / 2 \eta \\
\mu=-(I+A) / 2 \\
\omega=\mu^{2} / 2 \eta
\end{gathered}
$$

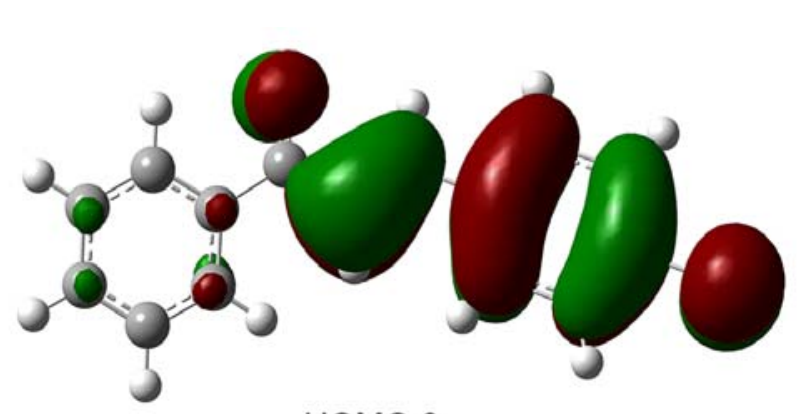

HOMO 3

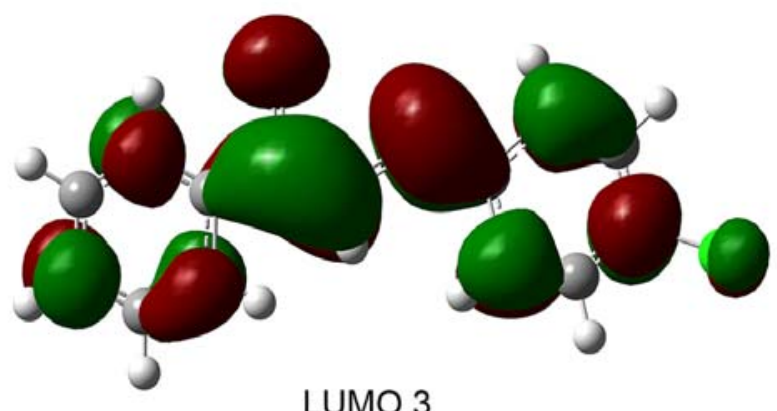

Figure 9. Calculated HOMO and LUMOs of Compound 3.

\section{Mulliken Atomic Charges}

The Mulliken charge distribution of the synthesized molecules were determined theoretically at the same level of theories. The Mulliken atomic charges for compounds $(E)$-6a and $(Z)$-6a were given in Figure 14 and Figure 15, respectively.

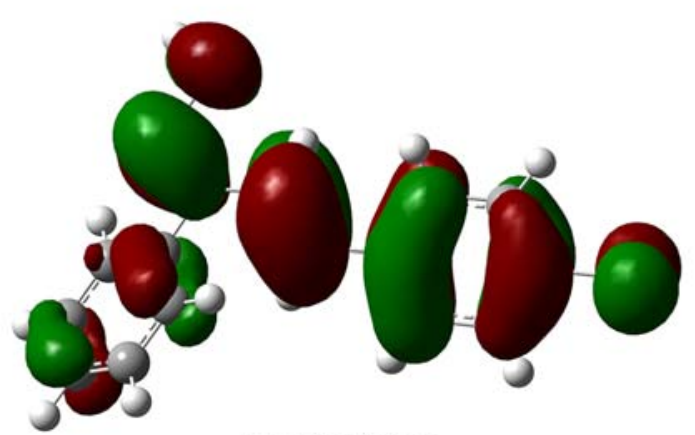

HOMO (E)-4

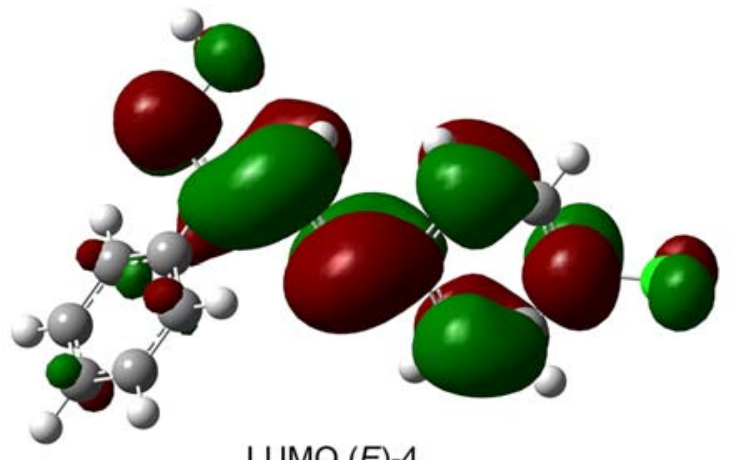

LUMO (E)-4

Figure 10. Calculated HOMO and LUMOs of Compound (E)4.
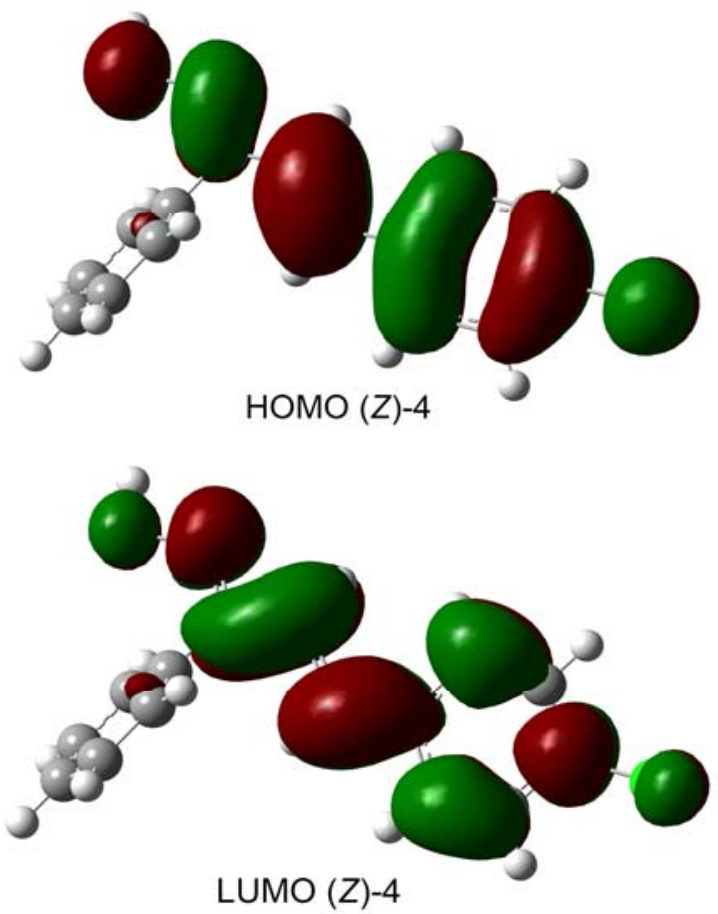

Figure 11. Calculated HOMO and LUMOs of Compound (Z)4. 


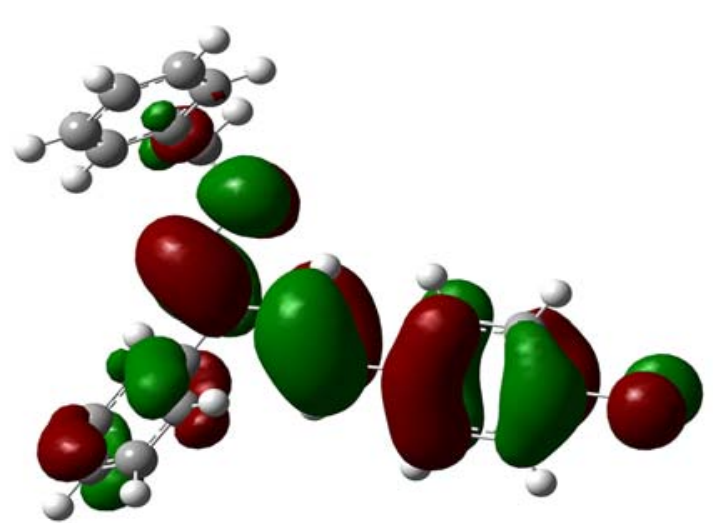

HOMO (E)-6a

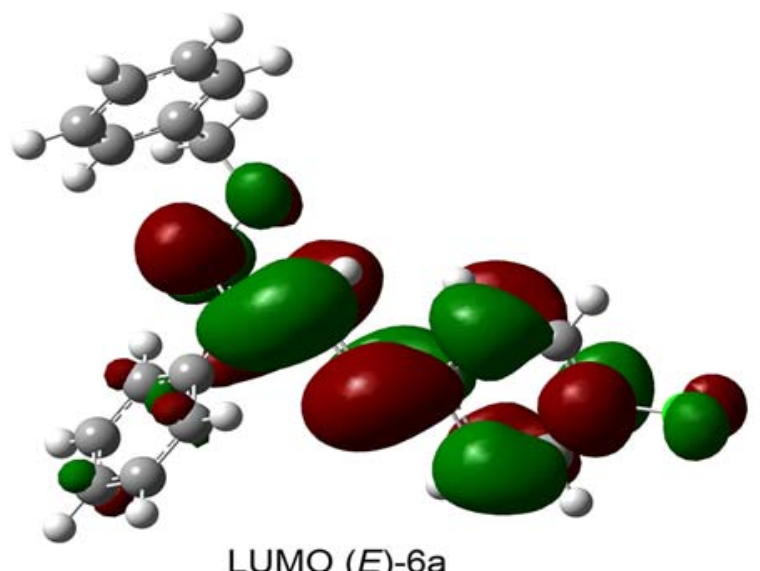

Figure 12. Calculated HOMO and LUMOs of Compound $(E)$ $6 a$.
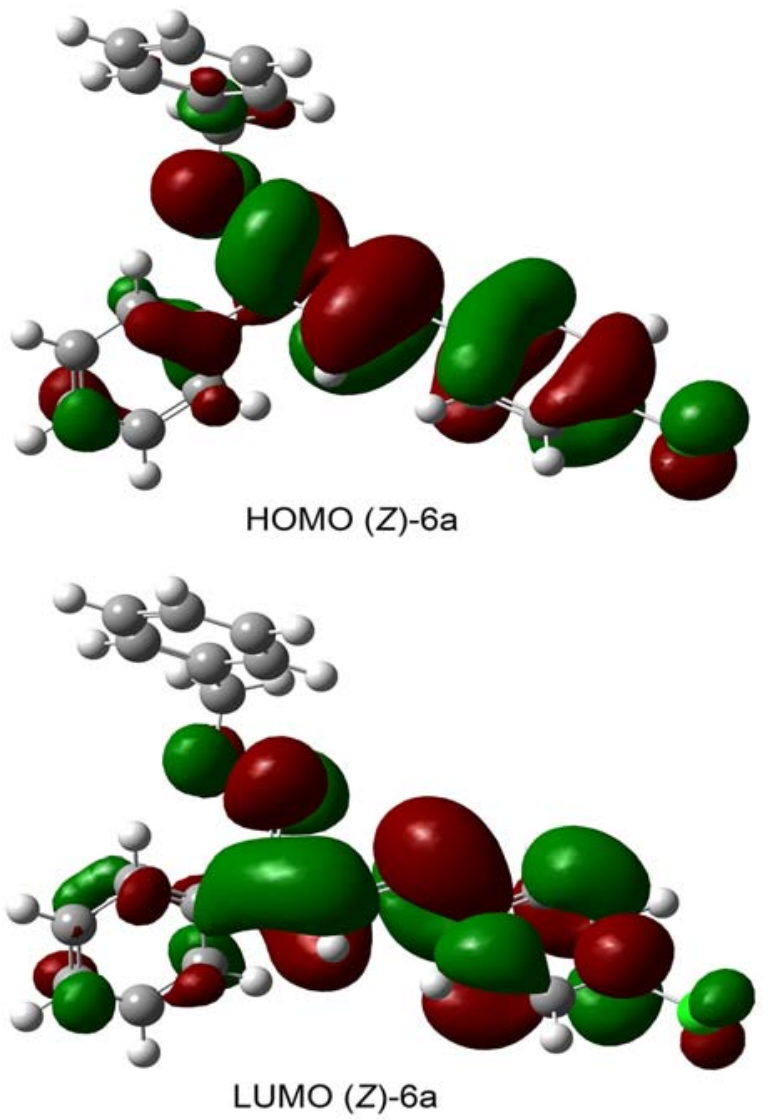

Figure 13. Calculated HOMO and LUMOs of Compound (Z)6 a.

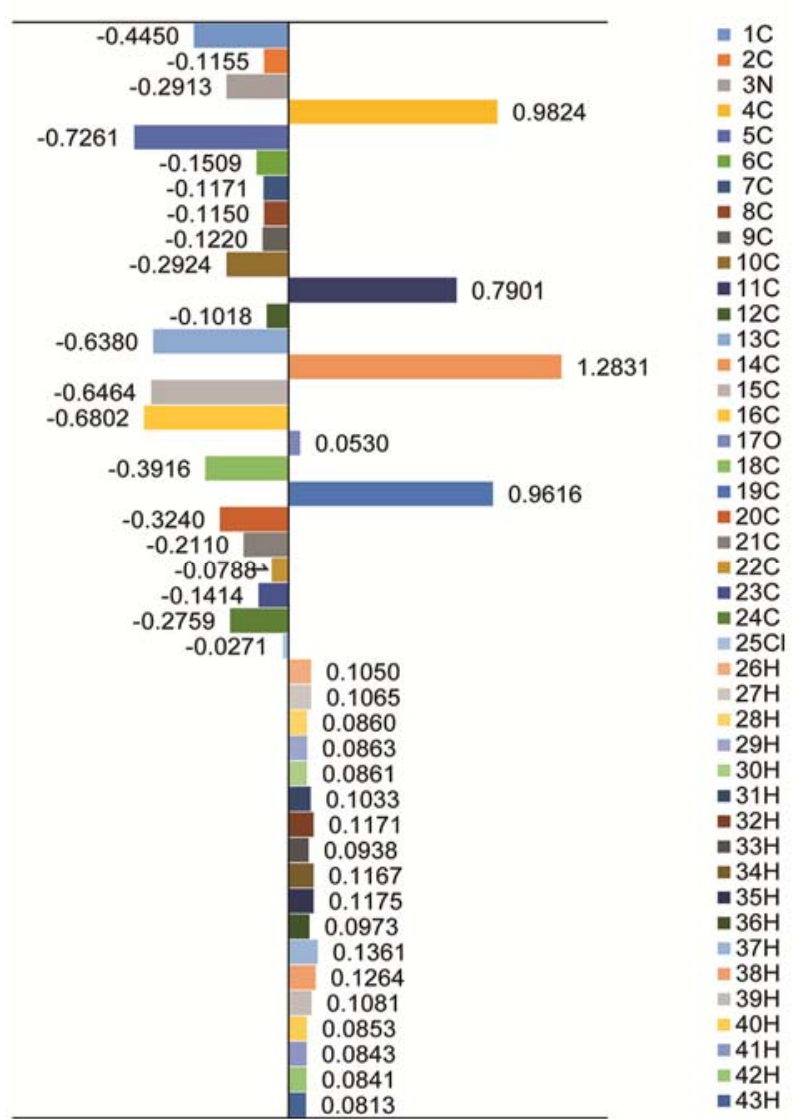

Figure 14. Calculated HOMO and LUMOs of Compound (E)$6 a$.

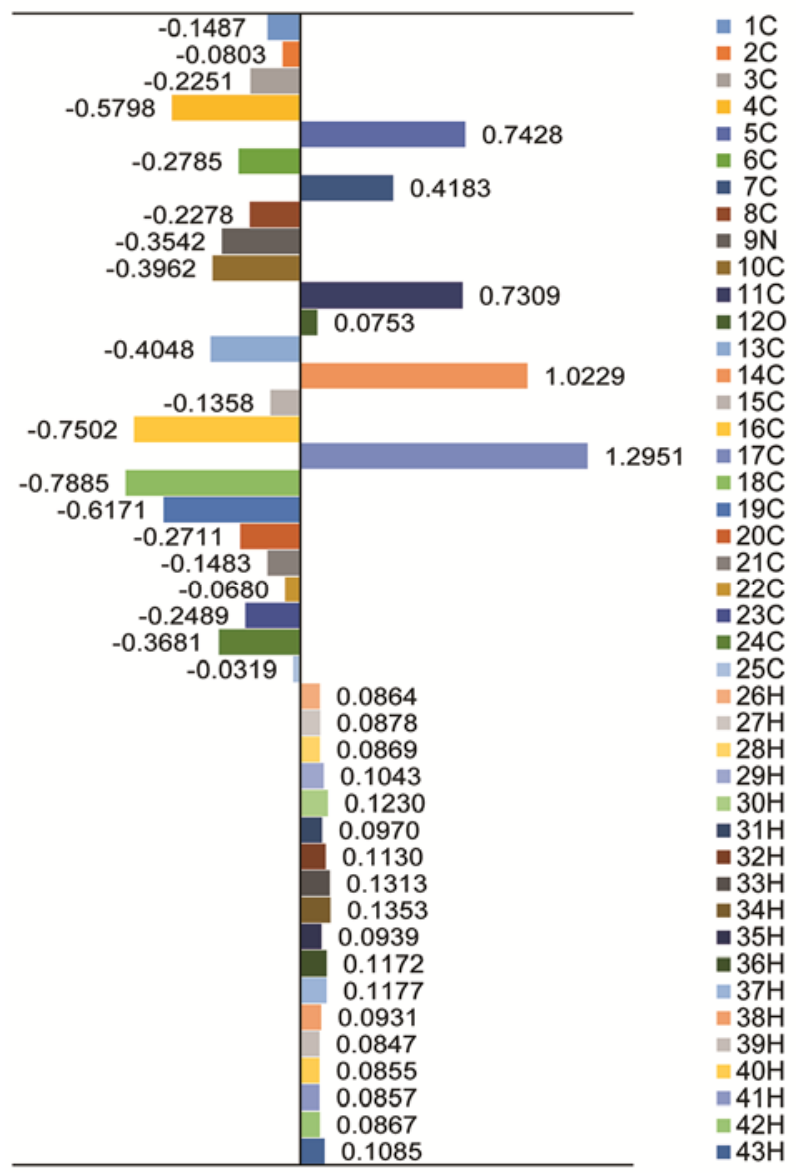

Figure 15. Calculated HOMO and LUMOs of Compound (Z)$6 a$. 
Table 4. Global Reactivity Descriptors (6-311+G(2d,p))

\begin{tabular}{lccccc}
\hline & Comp.3 & Comp. $(E)-4$ & Comp. $(Z)-4$ & Comp. $(E)-6 a$ & Comp. $(Z)-6 a$ \\
\hline LUMO & 2.63304 & -2.15352 & -1.98774 & -2.10546 & -2.03607 \\
HOMO & -6.642 & -6.17112 & -6.07527 & -6.03396 & -5.96592 \\
HOMO-LUMO Gap & 9.27504 & 4.0176 & 4.08753 & 3.9285 & 3.92985 \\
$I$ & 6.642 & 6.17112 & 6.07527 & 6.03396 & 5.96592 \\
$A$ & -2.63304 & 2.15352 & 1.98774 & 2.10546 & 2.03607 \\
$\chi$ & 2.00448 & 4.16232 & 4.031505 & 4.06971 & 4.000995 \\
$\eta$ & 4.63752 & 2.0088 & 2.043765 & 1.96425 & 1.964925 \\
$S$ & 0.107816247 & 0.248904819 & 0.244646522 & 0.254550083 & 0.254462639 \\
$\mu$ & -2.00448 & -4.16232 & -4.031505 & -4.06971 & -4.000995 \\
$\omega$ & 0.433199218 & 4.312253032 & 3.976247897 & 4.215995796 & 4.073427991 \\
\hline
\end{tabular}

\section{Discussion and Conclusion}

In conclusion, we have prepared some novel chalcone based oxime ethers, 3-(4-chlorophenyl)-1-phenyl-2propen-1-one $O$-benzyl oximes and we have characterized them using various characterization methods. We have also carried out some DFT calculations on the synthesized molecules.

In the synthesis of chalcone $\mathbf{3}$ from corresponding ketone $\mathbf{1}$ and aldehyde $\mathbf{2}$, the only product is $(E)$ isomer. It is not surprising to obtain only $(E)$-isomer because of its more stable molecular structure than the $(Z)$-isomer. The DFT calculations also support these experimental results. In all cases, the $(E)$ isomers were approximately $0.2 \mathrm{eV}$ lower in energy from the $(Z)$-isomers. The energies calculated for the $(E)$ - and (Z)-isomers of the compound $\mathbf{3}$ at the B3LYP/6-31G(d), B3LYP/6-311G(d,p) and B3LYP/6$311+G(2 d, p)$ level of theories and the energy difference between $(E)$ - and $(Z)$-isomers were given in Table 1.

In the synthesis of compound $\mathbf{4}$ from corresponding chalcone 3 , the product is a mixture of $(E)$ - and $(Z)$ isomers. The $E: Z$ molar ratio was found to be approximately 70:30. In all cases, the calculated energies for $(E)$-isomers were lower than the energies for $(Z)$-isomers but this energy differences are relatively small compared to the energy differences between the $(E)$ - and $(Z)$-isomers of chalcone 3. This explains why $(E)$-isomer is not the only product in the conversion of chalcone to the corresponding chalcone oxime. The energies calculated for the $(E)$ - and $(Z)$-isomers of the compound 4 and the energy difference between $(E)$ and $(Z)$-isomers were given in Table 1.

In the NMR spectral analysis, it can be said that there was a good agreement between the computational and experimental results. For the CSGT based NMR calculations it was found that the higher basis sets gave the best results. In GIAO based NMR calculations especially for certain protons the higher basis set overestimate the chemical shifts. When compared to the experimental values, it can be said that the best computational methods for the estimation of chemical shifts for the synthesized molecules are DFT B3LYP/6-311G(d,p) GIAO and DFT B3LYP/6$311+G(2 d, p)$ CSGT.

\section{Acknowledgment}

This work was supported by Kocaeli University Scientific Research Projects Unit. Project No: 2011/062. The authors acknowledge Kocaeli University for the financial support.

\section{References}

[1] Siddiqui, Z. N., Asad, M., Praveen, S. 2008. Synthesis and biological activity of heterocycles from chalcone. Medicinal Chemistry Research, 17, 318-325.

[2] Krishnakumar, B., Velmurugan, R., Swaminathan, M. 2011. $\mathrm{TiO}_{2}-\mathrm{SO}_{4}{ }^{2-}$ as a novel solid acid catalyst for highly efficient, solvent free and easy synthesis of chalcones under microwave irradiation. Catalysis Communications, 12, 375379.

[3] Dimmock, J. R., Elias, D. W., Beazely, M. A., Kandepu, N. M. 1999. Bioactivities of chalcones. Current Medicinal Chemistry, 6, 1125-1149.

[4] Xia, Y., Yang, Z. Y., Xia, P., Bastow, K. F., Nakanishi, Y., Lee, K. H. 2000. Antitumor agents. Part 202: novel 2'-amino chalcones: design, synthesis and biological evaluation. Bioorganic \& Medicinal Chemistry Letters, 10, 699-701.

[5] Liu, M., Wilairat, P., Go, M. L. 2001. Antimalarial alkoxylated and hydroxylated chalcones: structure:activity relationship analysis. Journal of Medicinal Chemistry, 44, 4443-4452.

[6] Dominguez, J. N., Charris, J. E., Lobo, G., de Dominguez, N. G., Moreno, M. M., Riggione, F., Sanchez, E., Olson, J., Rosenthal, P. J. 2001. Synthesis of quinolinyl chalcones and evaluation of their antimalarial activity. European Journal of Medicinal Chemistry, 36, 555-560.

[7] Ram, V. J., Saxena, A. S., Srivastava, S., Chandra, S. 2000. Oxygenated chalcones and bischalcones as potential antimalarial agents. Bioorganic \& Medicinal Chemistry Letters, 10, 2159-2161. 
[8] Herencia, F., Ferrandiz, M. L., Ubeda, A., Dominguez, J. N., Charris, J. E., Lobo, G. M., Alcaraz, M. J. 1998. Synthesis and antiimflammatory activity of chalcone derivatives. Bioorganic \& Medicinal Chemistry Letters, 8, 1169-1174.

[9] Lin, Y. M., Zhou, Y. S., Flavin, M. T., Zhou, L. M., Nie, W. G., Chen, F. C. 2002. Chalcones and flavonoids as anti-tuberculosis agents. Bioorganic \& Medicinal Chemistry, 10, 27952802.

[10] Satyanarayana, M., Tiwari, P., Tripathi, B. K., Srivastava, A. K., Pratap, R. 2004. Synthesis and antihyperglycemic activity of chalcone based aryloxypropanolamines. Bioorganic \& Medicinal Chemistry, 12, 883-889.

[11] Ducki, S., Forrest, R., Hadfield, J. A., Kendall, A., Lawrence, N. J., McGown, A. T., Rennison, D. 1998. Potent antimitotic and cell growth inhibitory properties of substituted chalcones. Bioorganic \& Medicinal Chemistry Letters, 8, 1051-1056.

[12] Xu, X. Y., Li, J. T., Du, C., Song, Y. L. 2011. Improved Synthesis of 1,3-Diaryl-2-propen-1one Oxime in the Presence of Anhydrous Sodium Sulfate. Chinese Journal of Chemistry, 29, 27812784.

[13] Luo, Y., Song, R., Li, Y., Zhang, S., Liu, Z.-J., Fu, J., Zhu, H.-L. 2012. Design, synthesis, and biological evaluation of chalcone oxime derivatives as potential immunosuppressive agents. Bioorganic \& Medicinal Chemistry Letters, 22, 3039-3043.

[14] Wang, Y.-T., Qin, Y.-J., Zhang, Y.-L., Li, Y.-J., Rao, B., Zhang, Y.-Q., Yang, M.-R., Jiang, A.-Q., Qi, J.-L., Zhu, H.-L. 2014. Synthesis, biological evaluation, and molecular docking studies of novel chalcone oxime derivatives as potential tubulin polymerization inhibitors. Rsc Advances, 4, 32263-32275.

[15] Chang, M.-Y., Chen, Y.-C., Chan, C.-K. 2014. Onepot synthesis of multifunctionalized cyclopropanes. Tetrahedron, 70, 2257-2263.

[16] Sinisterra, J. V., Garciaraso, A., Cabello, J. A, Marinas, J. M. 1984. An improved procedure for the Claisen-Schmidt reaction. SynthesisStuttgart, 502-504.

[17] Sebti, S., Solhy, A., Tahir, R., Boulaajaj, S., Mayoral, J. A., Fraile, J. M., Kossir, A., Oumimoun, H. 2001. Calcined sodium nitrate/natural phosphate: an extremely active catalyst for the easy synthesis of chalcones in heterogeneous media. Tetrahedron Letters, 42, 7953-7955.

[18] Zhu, X., Wang, Y.-F., Ren, W., Zhang, F.-L., Chiba, S. 2013. TEMPO-Mediated Aliphatic C-H oxidation with oximes and hydrazones. Organic Letters, 15, 3214-3217.
[19] Liu, S., Liebeskind, L. S. 2008. A simple, modular synthesis of substituted pyridines. Journal of the American Chemical Society, 130, 6918-6919.

[20] Sinisterra, J. V., Marinas, J. M. 1987. Barium hydroxide as the catalyst in organic reactions. Part X. Reaction of chalcone with hydroxylamine. Bulletin Des Societes Chimiques Belges, 96, 293-302.

[21] Hyster, T. K., Rovis, T. 2011. Pyridine synthesis from oximes and alkynes via rhodium (iii) catalysis: $\mathrm{Cp}^{*}$ and $\mathrm{Cp}$ t provide complementary selectivity. Chemical Communications, 47, 11846-11848.

[22] Frisch M.J., Trucks, G.W., Schlegel, H.B., Scuseria, G.E., Robb, M.A., Cheeseman, J.R., Scalmani, G., Barone, V., Mennucci, B., Petersson, G.A., Nakatsuji, H., Caricato, M., Li, X., Hratchian, H.P., Izmaylov, A.F., Bloino, J., Zheng, G., Sonnenberg, J.L., Hada, M., Ehara, M., Toyota, K., Fukuda, R., Hasegawa, J., Ishida, M., Nakajima, T., Honda, Y., Kitao, O., Nakai, H., Vreven, T., Montgomery, Jr., J.A., Peralta, J.E., Ogliaro, F., Bearpark, M., Heyd, J.J., Brothers, E., Kudin, K.N., Staroverov, V.N., Keith, T., Kobayashi, R., Normand, J., Raghavachari, K., Rendell, A., Burant, J.C., Iyengar, S.S., Tomasi, J., Cossi, M., Rega, N., Millam, J.M., Klene, M., Knox, J.E., Cross, J.B., Bakken, V., Adamo, C., Jaramillo, J., Gomperts, R., Stratmann, R.E., Yazyev, O., Austin, A.J., Cammi, R., Pomelli, C., Ochterski, J.W., Martin, R.L., Morokuma, K., Zakrzewski, V.G., Voth, G.A., Salvador, P., Dannenberg, J.J., Dapprich, S., Daniels, A.D., Farkas, O., Foresman, J.B., Ortiz, J.V., Cioslowski, J., Fox, D.J. 2013. Gaussian, Inc., Wallingford CT.

[23] GaussView, Version 5, Dennington, R.; Keith, T.; Millam, J. 2009. Semichem Inc., Shawnee Mission, KS.

[24] Koopmans, T. 1933. Über die Zuordnung von Wellenfunktionen und Eigenwerten $\mathrm{zu}$ den Einzelnen Elektronen Eines Atoms. Physica, 1, 104.

[25] Mulliken, R. S. 1934. A new electroaffinity scale; together with data on valence states and on valence ionization potentials and electron affinities. J. Chem.Phys., 2, 782.

[26] Pearson, R. G. 1963. Hard and soft acids and bases. J. Am. Chem. Soc., 85, 3533.

[27] Pearson, R. G. 1968. Hard and soft acids and bases, HSAB, part 1: fundamental principles. J. Chem. Educ., 45, 581.

[28] Pearson, R. G. 1999. Maximum chemical and physical hardness. J. Chem. Educ., 76, 267.

[29] Parr, R. G.; Pearson R. G. 1983. Absolute hardness: companion parameter to absolute electronegativity. J. Am. Chem. Soc., 105, 7512. 
[30] Parr, R. G.; Szentpaly, L.; Liu, S. 1999. Electrophilicity index. J. Am. Chem. Soc., 121, 1922.

[31] Chattaraj, P. K.; Sarkar, U.; Roy, D. R. 2006. Electrophilicity index. Chem. Rev., 106, 2065.

\section{Appendices}

Appendix A. Calculated Molecular Structures

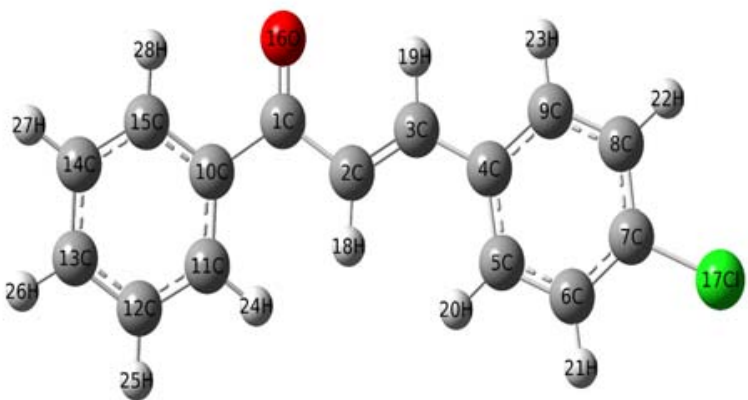

Figure A.1. Calculated Molecular Structure of Compound 3.

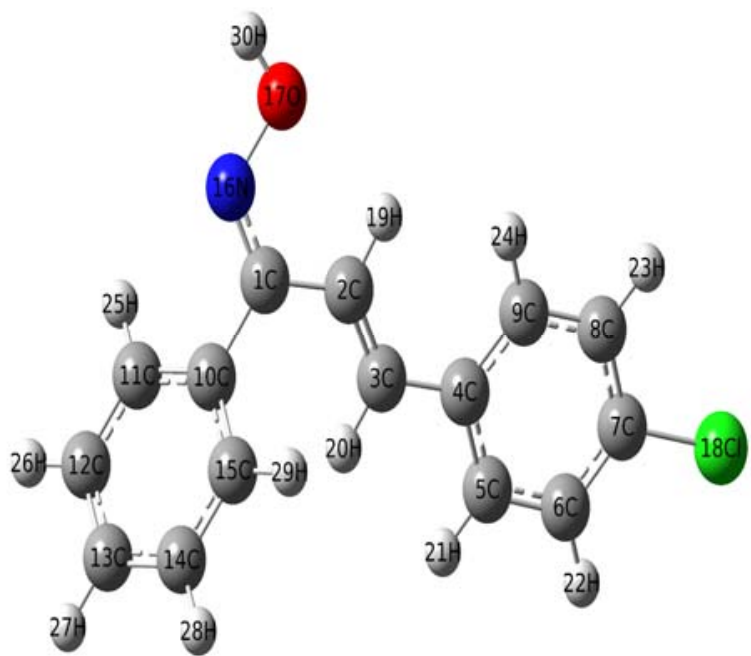

Figure A.2. Calculated Molecular Structure of Compound $(E)-4$.

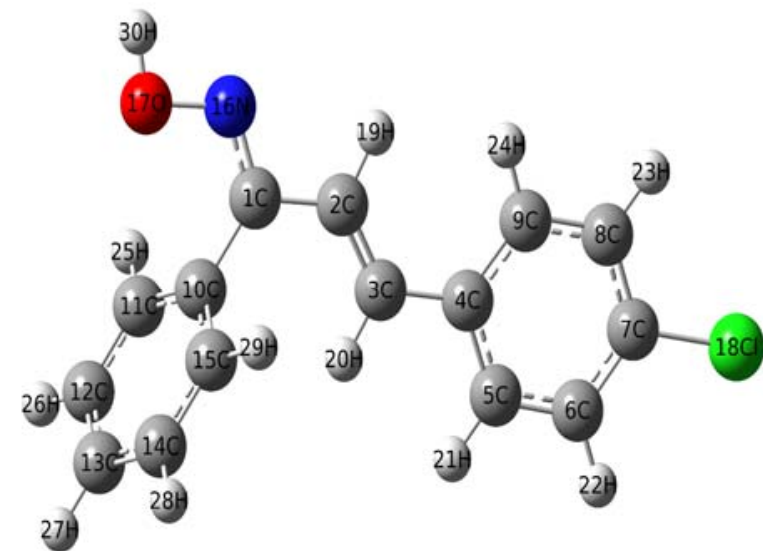

Figure A.3. Calculated Molecular Structure of Compound $(Z)-4$.

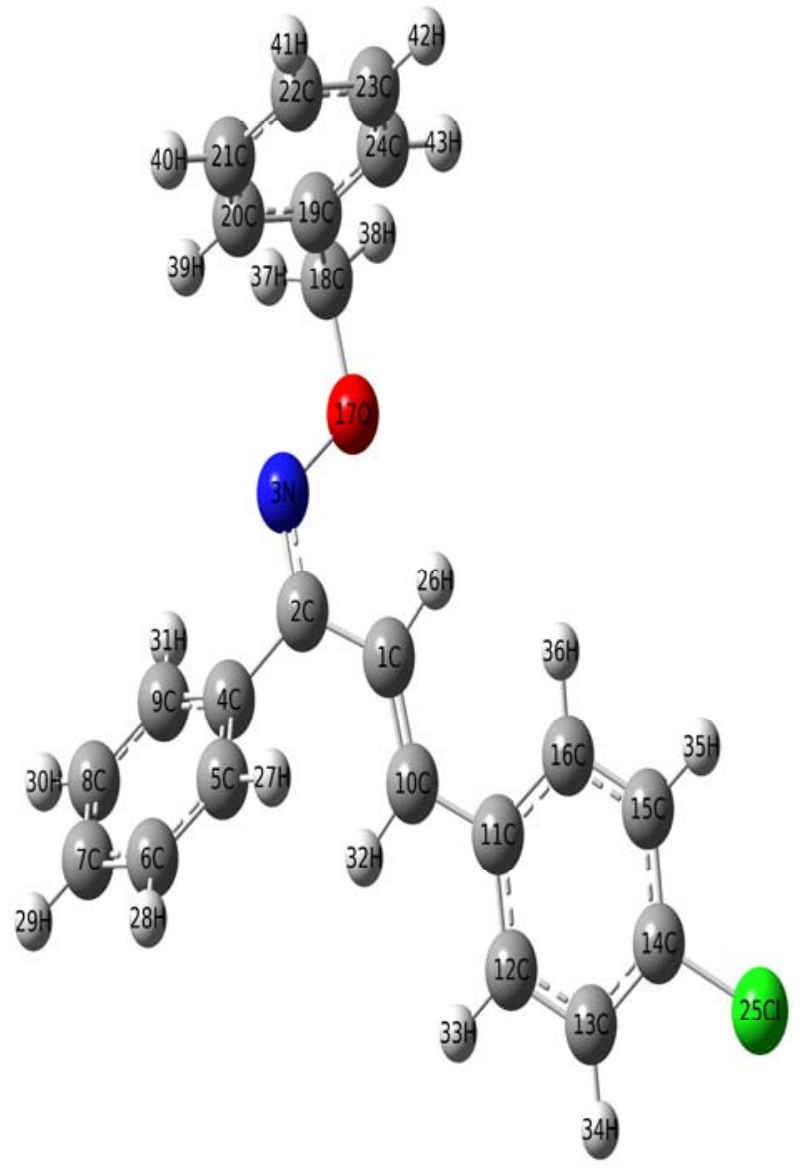

Figure A.4. Calculated Molecular Structure of Compound (E)-6a.

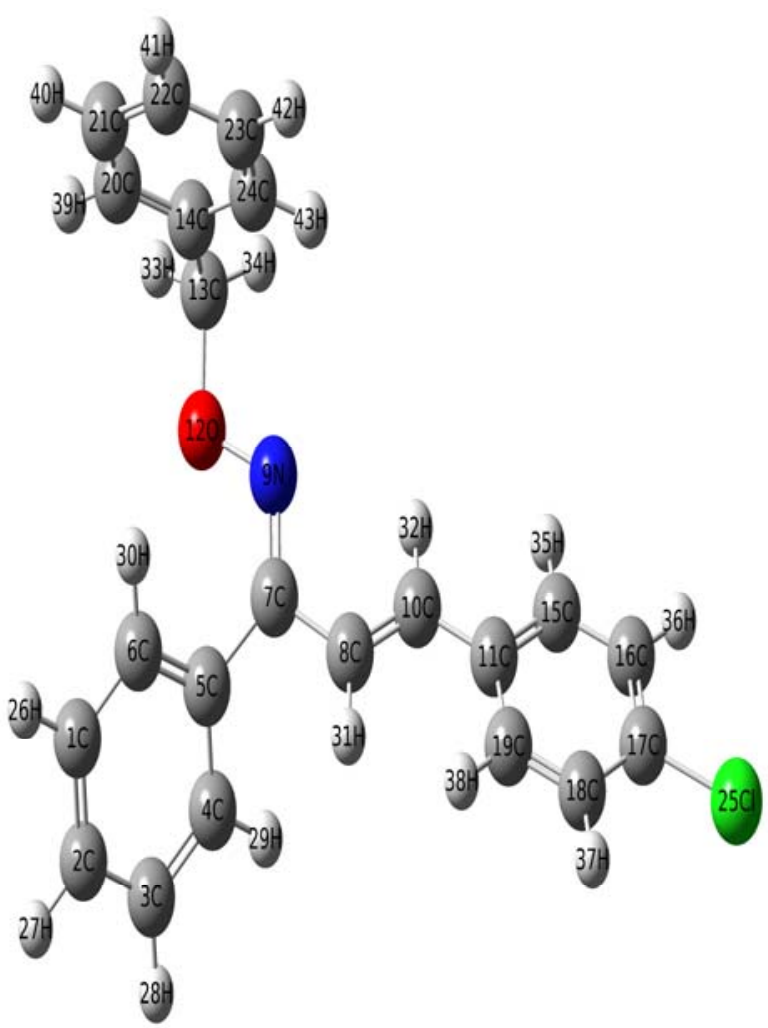

Figure A.5. Calculated Molecular Structure of Compound (Z)-6a. 
Appendix B. Calculated Geometric Parameters

Table B.1. Calculated Bond Lengths, Bond Angels and Dihedral Angles for Compound 3.

\begin{tabular}{|c|c|c|c|c|c|}
\hline Atoms & Bond Length & Atoms & Bond Angle & Atoms & Dihedral Angle \\
\hline C15-H28 & 1.082 & H28-C15-C14 & 121.13 & C13-C14-C15-C10 & -0.61 \\
\hline $\mathrm{C} 14-\mathrm{H} 27$ & 1.083 & H28-C15-C10 & 118.21 & C13-C14-C15-H28 & 179.34 \\
\hline C14-C15 & 1.386 & C14-C15-C10 & 120.66 & H27-C14-C15-C10 & 179.52 \\
\hline C13-H26 & 1.084 & H27-C14-C15 & 119.92 & H27-C14-C15-H28 & -0.53 \\
\hline C13-C14 & 1.394 & H27-C14-C13 & 120.02 & C12-C13-C14-C15 & 0.05 \\
\hline $\mathrm{C} 12-\mathrm{H} 25$ & 1.083 & C15-C14-C13 & 120.07 & C12-C13-C14-H27 & 179.92 \\
\hline C12-C13 & 1.390 & H26-C13-C14 & 120.11 & H26-C13-C14-C15 & -179.82 \\
\hline C11-H24 & 1.082 & H26-C13-C12 & 120.04 & H26-C13-C14-H27 & 0.05 \\
\hline C11-C12 & 1.391 & C14-C13-C12 & 119.85 & C11-C12-C13-C14 & 0.52 \\
\hline C10-C15 & 1.400 & H25-C12-C13 & 120.12 & C11-C12-C13-H26 & -179.61 \\
\hline C10-C11 & 1.399 & H25-C12-C11 & 119.81 & H25-C12-C13-C14 & -179.42 \\
\hline C9-H23 & 1.084 & C13-C12-C11 & 120.08 & H25-C12-C13-H26 & 0.45 \\
\hline $\mathrm{C} 8-\mathrm{H} 22$ & 1.082 & H24-C11-C12 & 118.77 & C10-C11-C12-C13 & -0.54 \\
\hline C8-C9 & 1.388 & H24-C11-C10 & 120.67 & C10-C11-C12-H25 & 179.40 \\
\hline $\mathrm{C} 7-\mathrm{Cl} 17$ & 1.753 & C12-C11-C10 & 120.54 & H24-C11-C12-C13 & -179.26 \\
\hline C7-C8 & 1.387 & C15-C10-C11 & 118.79 & H24-C11-C12-H25 & 0.68 \\
\hline C6-H21 & 1.082 & C15-C10-C1 & 117.72 & C1-C10-C15-C14 & 179.55 \\
\hline C6-C7 & 1.392 & C11-C10-C1 & 123.48 & C1-C10-C15-H28 & -0.40 \\
\hline C5-H20 & 1.083 & H23-C9-C8 & 119.20 & C11-C10-C15-C14 & 0.59 \\
\hline C5-C6 & 1.384 & H23-C9-C4 & 119.18 & C11-C10-C15-H28 & -179.37 \\
\hline C4-C9 & 1.402 & C8-C9-C4 & 121.62 & C1-C10-C11-C12 & -178.91 \\
\hline $\mathrm{C} 4-\mathrm{C} 5$ & 1.404 & H22-C8-C9 & 120.80 & C1-C10-C11-H24 & -0.22 \\
\hline C3-H19 & 1.087 & H22-C8-C7 & 120.20 & C15-C10-C11-C12 & -0.01 \\
\hline C3-C4 & 1.459 & C9-C8-C7 & 119.00 & C15-C10-C11-H24 & 178.68 \\
\hline C2-H18 & 1.081 & $\mathrm{Cl} 17-\mathrm{C} 7-\mathrm{C} 8$ & 119.64 & C7-C8-C9-C4 & -0.02 \\
\hline $\mathrm{C} 2-\mathrm{C} 3$ & 1.342 & Cl17-C7-C6 & 119.40 & C7-C8-C9-H23 & -180.00 \\
\hline C1-016 & 1.223 & C8-C7-C6 & 120.96 & H22-C8-C9-C4 & 179.98 \\
\hline C1-C10 & 1.501 & H21-C6-C7 & 119.93 & H22-C8-C9-H23 & 0.01 \\
\hline $\mathrm{C} 1-\mathrm{C} 2$ & 1.484 & H21-C6-C5 & 120.70 & C6-C7-C8-C9 & -0.04 \\
\hline & & $\mathrm{C} 7-\mathrm{C} 6-\mathrm{C} 5$ & 119.37 & С6-C7-C8-H22 & 179.96 \\
\hline & & H20-C5-C6 & 118.61 & Cl17-C7-C8-C9 & 179.99 \\
\hline & & $\mathrm{H} 20-\mathrm{C} 5-\mathrm{C} 4$ & 120.13 & Cl17-C7-C8-H22 & -0.02 \\
\hline & & C6-C5-C4 & 121.27 & С5-C6-C7-C8 & 0.04 \\
\hline & & C9-C4-C5 & 117.78 & C5-C6-C7-Cl17 & -179.98 \\
\hline & & C9-C4-C3 & 118.67 & H21-C6-C7-C8 & -179.91 \\
\hline & & C5-C4-C3 & 123.55 & $\mathrm{H} 21-\mathrm{C} 6-\mathrm{C} 7-\mathrm{Cl} 17$ & 0.07 \\
\hline & & H19-C3-C4 & 115.92 & C4-C5-C6-C7 & 0.02 \\
\hline & & H19-C3-C2 & 116.13 & C4-C5-C6-H21 & 179.97 \\
\hline & & C4-C3-C2 & 127.95 & H20-C5-C6-C7 & -179.92 \\
\hline & & $\mathrm{H} 18-\mathrm{C} 2-\mathrm{C} 3$ & 121.05 & $\mathrm{H} 20-\mathrm{C} 5-\mathrm{C} 6-\mathrm{H} 21$ & 0.03 \\
\hline & & H18-C2-C1 & 118.64 & C3-C4-C9-C8 & -179.90 \\
\hline & & C3-C2-C1 & 120.30 & C3-C4-C9-H23 & 0.07 \\
\hline & & 016-C1-C10 & 119.88 & С5-C4-C9-С8 & 0.08 \\
\hline & & 016-C1-C2 & 121.12 & С5-C4-C9-H23 & -179.94 \\
\hline & & C10-C1-C2 & 119.00 & C3-C4-C5-C6 & 179.90 \\
\hline & & & & C3-C4-C5-H2O & -0.16 \\
\hline & & & & С9-С4-С5-С6 & -0.08 \\
\hline & & & & С9-C4-C5-H2O & 179.86 \\
\hline & & & & $\mathrm{C} 2-\mathrm{C} 3-\mathrm{C} 4-\mathrm{C} 5$ & -0.44 \\
\hline & & & & C2-C3-C4-C9 & 179.54 \\
\hline & & & & H19-C3-C4-C5 & 179.46 \\
\hline & & & & H19-C3-C4-C9 & -0.55 \\
\hline & & & & C1-C2-C3-C4 & 179.12 \\
\hline & & & & C1-C2-C3-H19 & -0.78 \\
\hline & & & & H18-C2-C3-C4 & 0.38 \\
\hline & & & & H18-C2-C3-H19 & -179.53 \\
\hline & & & & C2-C1-C10-C11 & -14.79 \\
\hline & & & & C2-C1-C10-C15 & 166.30 \\
\hline & & & & 016-C1-C10-C11 & 166.05 \\
\hline & & & & 016-C1-C10-C15 & -12.86 \\
\hline & & & & C10-C1-C2-C3 & 177.31 \\
\hline & & & & C10-C1-C2-H18 & -3.92 \\
\hline & & & & 016-C1-C2-C3 & -3.55 \\
\hline & & & & 016-C1-C2-H18 & 175.23 \\
\hline
\end{tabular}

Table B.2. Calculated Bond Lengths, Bond Angels and Dihedral Angles for Compound $(E)-4$

\begin{tabular}{cccccc} 
Atoms & Bond Length & Atoms & Bond Angle & Atoms & Dihedral Angle \\
\hline O17-H30 & 0.964 & H30-O17-N16 & 102.12 & C1-N16-O17-H30 & -176.41 \\
N16-017 & 1.408 & O17-N16-C1 & 112.86 & C13-C14-C15-C10 & 0.40 \\
C15-H29 & 1.083 & H29-C15-C14 & 119.76 & C13-C14-C15-H29 & 179.23 \\
C14-H28 & 1.084 & H29-C15-C10 & 119.70 & H28-C14-C15-C10 & -179.28 \\
C14-C15 & 1.390 & C14-C15-C10 & 120.53 & H28-C14-C15-H29 & -0.45
\end{tabular}




$\begin{array}{cc}\text { C13-H27 } & 1.084 \\ \text { C13-C14 } & 1.392 \\ \text { C12-H26 } & 1.084 \\ \text { C12-C13 } & 1.391 \\ \text { C11-H25 } & 1.082 \\ \text { C11-C12 } & 1.390 \\ \text { C10-C15 } & 1.398 \\ \text { C10-C11 } & 1.397 \\ \text { C9-H24 } & 1.082 \\ \text { C8-H23 } & 1.082 \\ \text { C8-C9 } & 1.385 \\ \text { C7-Cl18 } & 1.755 \\ \text { C7-C8 } & 1.391 \\ \text { C6-H22 } & 1.082 \\ \text { C6-C7 } & 1.387 \\ \text { C5-H21 } & 1.084 \\ \text { C5-C6 } & 1.388 \\ \text { C4-C9 } & 1.404 \\ \text { C4-C5 } & 1.402 \\ \text { C3-H20 } & 1.085 \\ \text { C3-C4 } & 1.462 \\ \text { C2-H19 } & 1.082 \\ \text { C2-C3 } & 1.344 \\ \text { C1-N16 } & 1.290 \\ \text { C1-C10 } & 1.490 \\ \text { C1-C2 } & 1.460\end{array}$

\begin{tabular}{cc} 
H28-C14-C15 & 119.71 \\
H28-C14-C13 & 120.09 \\
C15-C14-C13 & 120.20 \\
H27-C13-C14 & 120.14 \\
H27-C13-C12 & 120.20 \\
C14-C13-C12 & 119.66 \\
H26-C12-C13 & 120.08 \\
H26-C12-C11 & 119.72 \\
C13-C12-C11 & 120.20 \\
H25-C11-C12 & 120.38 \\
H25-C11-C10 & 119.05 \\
C12-C11-C10 & 120.57 \\
C15-C10-C11 & 118.85 \\
C15-C10-C1 & 121.03 \\
C11-C10-C1 & 120.10 \\
H24-C9-C8 & 118.55 \\
H24-C9-C4 & 120.17 \\
C8-C9-C4 & 121.28 \\
H23-C8-C9 & 120.59 \\
H23-C8-C7 & 119.95 \\
C9-C8-C7 & 119.46 \\
Cl18-C7-C8 & 119.48 \\
Cl18-C7-C6 & 119.65 \\
C8-C7-C6 & 120.86 \\
H22-C6-C7 & 120.21 \\
H22-C6-C5 & 120.76 \\
C7-C6-C5 & 119.03 \\
H21-C5-C6 & 119.06 \\
H21-C5-C4 & 119.23 \\
C6-C5-C4 & 121.70 \\
C9-C4-C5 & 117.67 \\
C9-C4-C3 & 123.59 \\
C5-C4-C3 & 118.74 \\
H20-C3-C4 & 114.71 \\
H20-C3-C2 & 118.47 \\
C4-C3-C2 & 126.82 \\
H19-C2-C3 & 120.48 \\
H19-C2-C1 & 114.92 \\
C3-C2-C1 & 124.55 \\
N16-C1-C10 & 114.27 \\
N16-C1-C2 & 123.59 \\
C10-C1-C2 & 122.14 \\
& \\
\hline
\end{tabular}

\begin{tabular}{|c|c|}
\hline C12-C13-C14-C15 & -0.32 \\
\hline С12-C13-C14-H28 & 179.36 \\
\hline H27-C13-C14-C15 & 179.72 \\
\hline H27-C13-C14-H28 & -0.61 \\
\hline C11-C12-C13-C14 & 0.01 \\
\hline C11-C12-C13-H27 & 179.97 \\
\hline Н26-C12-C13-C14 & 179.92 \\
\hline H26-C12-C13-H27 & -0.12 \\
\hline C10-C11-C12-C13 & 0.22 \\
\hline C10-C11-C12-H26 & -179.69 \\
\hline H25-C11-C12-C13 & -179.70 \\
\hline H25-C11-C12-H26 & 0.40 \\
\hline C1-C10-C15-C14 & 178.20 \\
\hline C1-C10-C15-H29 & -0.63 \\
\hline C11-C10-C15-C14 & -0.17 \\
\hline C11-C10-C15-H29 & -179.00 \\
\hline C1-C10-C11-C12 & -178.53 \\
\hline C1-C10-C11-H25 & 1.39 \\
\hline C15-C10-C11-C12 & -0.14 \\
\hline C15-C10-C11-H25 & 179.78 \\
\hline C7-С8-С9-С4 & -0.01 \\
\hline С7-C8-C9-H24 & 179.85 \\
\hline $\mathrm{H} 23-\mathrm{C} 8-\mathrm{C} 9-\mathrm{C} 4$ & -179.97 \\
\hline Н23-С8-С9-H24 & -0.11 \\
\hline С6-C7-C8-C9 & -0.05 \\
\hline С6-C7-C8-H23 & 179.90 \\
\hline Cl18-C7-C8-C9 & -179.97 \\
\hline Cl18-C7-C8-H23 & -0.02 \\
\hline C5-C6-C7-C8 & 0.01 \\
\hline C5-C6-C7-Cl18 & 179.93 \\
\hline H22-C6-C7-C8 & -180.00 \\
\hline H22-C6-C7-Cl18 & -0.08 \\
\hline C4-C5-C6-C7 & 0.11 \\
\hline C4-C5-C6-H22 & -179.88 \\
\hline H21-C5-C6-C7 & 179.95 \\
\hline H21-C5-C6-H22 & -0.04 \\
\hline C3-C4-C9-C8 & -179.87 \\
\hline С3-С4-С9-H24 & 0.27 \\
\hline С5-C4-C9-C8 & 0.12 \\
\hline С5-C4-C9-H24 & -179.73 \\
\hline C3-C4-C5-C6 & 179.82 \\
\hline C3-C4-C5-H21 & -0.02 \\
\hline C9-C4-C5-C6 & -0.17 \\
\hline C9-C4-C5-H21 & 179.99 \\
\hline C2-C3-C4-C5 & -176.87 \\
\hline C2-C3-C4-C9 & 3.12 \\
\hline $\mathrm{H} 20-\mathrm{C} 3-\mathrm{C} 4-\mathrm{C} 5$ & 2.15 \\
\hline $\mathrm{H} 20-\mathrm{C} 3-\mathrm{C} 4-\mathrm{C} 9$ & -177.86 \\
\hline C1-C2-C3-C4 & 178.82 \\
\hline $\mathrm{C} 1-\mathrm{C} 2-\mathrm{C} 3-\mathrm{H} 20$ & -0.17 \\
\hline H19-C2-C3-C4 & 1.39 \\
\hline H19-C2-C3-H20 & -177.60 \\
\hline C2-C1-N16-017 & 2.28 \\
\hline C10-C1-N16-017 & -177.50 \\
\hline C2-C1-C10-C11 & -130.91 \\
\hline C2-C1-C10-C15 & 50.74 \\
\hline N16-C1-C10-C11 & 48.88 \\
\hline N16-C1-C10-C15 & -129.48 \\
\hline C10-C1-C2-C3 & 15.86 \\
\hline C10-C1-C2-H19 & -166.58 \\
\hline N16-C1-C2-C3 & -163.91 \\
\hline N16-C1-C2-H19 & 13.65 \\
\hline
\end{tabular}

Table B.3. Calculated Bond Lengths, Bond Angels and Dihedral Angles for Compound (Z)-4

\begin{tabular}{cccccc}
\hline Atoms & Bond Length & Atoms & Bond Angle & Atoms & Dihedral Angle \\
\hline O17-H30 & 0.965 & H30-O17-N16 & 102.41 & C1-N16-O17-H30 & 178.86 \\
N16-O17 & 1.399 & O17-N16-C1 & 112.87 & C13-C14-C15-C10 & 0.48 \\
C15-H29 & 1.084 & H29-C15-C14 & 119.99 & C13-C14-C15-H29 & -179.93 \\
C14-H28 & 1.084 & H29-C15-C10 & 119.64 & H28-C14-C15-C10 & -179.53 \\
C14-C15 & 1.391 & C14-C15-C10 & 120.37 & H28-C14-C15-H29 & 0.06 \\
C13-H27 & 1.083 & H28-C14-C15 & 119.75 & C12-C13-C14-C15 & -0.27 \\
C13-C14 & 1.391 & H28-C14-C13 & 120.14 & C12-C13-C14-H28 & 179.74 \\
C12-H26 & 1.084 & C15-C14-C13 & 120.11 & H27-C13-C14-C15 & 179.81 \\
C12-C13 & 1.391 & H27-C13-C14 & 120.11 & H27-C13-C14-H28 & -0.18 \\
C11-H25 & 1.083 & H27-C13-C12 & 120.12 & C11-C12-C13-C14 & -0.17 \\
C11-C12 & 1.390 & C14-C13-C12 & 119.77 & C11-C12-C13-H27 & 179.76
\end{tabular}


T. Erdoğan / The First Synthesis of Some Novel 4-Chloro Chalcone Based Oxime Ethers: An Experimental and Computational Study.

$\begin{array}{cl}\text { C10-C15 } & 1.396 \\ \text { C10-C11 } & 1.396 \\ \text { C9-H24 } & 1.083 \\ \text { C8-H23 } & 1.082 \\ \text { C8-C9 } & 1.385 \\ \text { C7-Cl18 } & 1.755 \\ \text { C7-C8 } & 1.391 \\ \text { C6-H22 } & 1.082 \\ \text { C6-C7 } & 1.387 \\ \text { C5-H21 } & 1.084 \\ \text { C5-C6 } & 1.388 \\ \text { C4-C9 } & 1.404 \\ \text { C4-C5 } & 1.402 \\ \text { C3-H20 } & 1.085 \\ \text { C3-C4 } & 1.462 \\ \text { C2-H19 } & 1.085 \\ \text { C2-C3 } & 1.344 \\ \text { C1-N16 } & 1.289 \\ \text { C1-C10 } & 1.492 \\ \text { C1-C2 } & 1.457\end{array}$

\begin{tabular}{cc} 
H26-C12-C13 & 120.09 \\
H26-C12-C11 & 119.73 \\
C13-C12-C11 & 120.18 \\
H25-C11-C12 & 120.10 \\
H25-C11-C10 & 119.57 \\
C12-C11-C10 & 120.33 \\
C15-C10-C11 & 119.25 \\
C15-C10-C1 & 120.24 \\
C11-C10-C1 & 120.51 \\
H24-C9-C8 & 118.48 \\
H24-C9-C4 & 120.17 \\
C8-C9-C4 & 121.35 \\
H23-C8-C9 & 120.57 \\
H23-C8-C7 & 119.96 \\
C9-C8-C7 & 119.47 \\
Cl18-C7-C8 & 119.50 \\
Cl18-C7-C6 & 119.69 \\
C8-C7-C6 & 120.81 \\
H22-C6-C7 & 120.21 \\
H22-C6-C5 & 120.73 \\
C7-C6-C5 & 119.07 \\
H21-C5-C6 & 119.04 \\
H21-C5-C4 & 119.22 \\
C6-C5-C4 & 121.75 \\
C9-C4-C5 & 117.56 \\
C9-C4-C3 & 123.64 \\
C5-C4-C3 & 118.80 \\
H20-C3-C4 & 114.97 \\
H20-C3-C2 & 118.16 \\
C4-C3-C2 & 126.87 \\
H19-C2-C3 & 121.20 \\
H19-C2-C1 & 113.95 \\
C3-C2-C1 & 124.85 \\
N16-C1-C10 & 124.00 \\
N16-C1-C2 & 114.61 \\
C10-C1-C2 & 121.40 \\
& \\
\hline
\end{tabular}

\begin{tabular}{|c|c|}
\hline Н26-C12-C13-C14 & -179.95 \\
\hline Н26-C12-C13-H27 & -0.03 \\
\hline C10-C11-C12-C13 & 0.40 \\
\hline C10-C11-C12-Н26 & -179.82 \\
\hline $\mathrm{H} 25-\mathrm{C} 11-\mathrm{C} 12-\mathrm{C} 13$ & -179.38 \\
\hline H25-C11-C12-H26 & 0.40 \\
\hline C1-C10-C15-C14 & -179.95 \\
\hline C1-C10-C15-H29 & 0.46 \\
\hline C11-C10-C15-C14 & -0.24 \\
\hline C11-C10-C15-H29 & -179.84 \\
\hline C1-C10-C11-C12 & 179.51 \\
\hline C1-C10-C11-H25 & -0.71 \\
\hline C15-C10-C11-C12 & -0.19 \\
\hline C15-C10-C11-H25 & 179.59 \\
\hline C7-C8-C9-C4 & -0.04 \\
\hline С7-С8-С9-Н24 & 179.78 \\
\hline H23-C8-C9-C4 & -179.96 \\
\hline Н23-С8-С9-H24 & -0.13 \\
\hline С6-C7-C8-C9 & -0.06 \\
\hline C6-C7-C8-H23 & 179.86 \\
\hline Cl18-C7-C8-C9 & -179.96 \\
\hline Cl18-C7-C8-H23 & -0.04 \\
\hline C5-C6-C7-C8 & 0.04 \\
\hline C5-C6-C7-Cl18 & 179.94 \\
\hline H22-C6-C7-C8 & -179.95 \\
\hline H22-C6-C7-Cl18 & -0.04 \\
\hline C4-C5-C6-C7 & 0.08 \\
\hline С4-C5-C6-H22 & -179.93 \\
\hline H21-C5-C6-C7 & 179.97 \\
\hline H21-C5-C6-H22 & -0.05 \\
\hline С3-C4-C9-C8 & -179.87 \\
\hline С3-С4-С9-Н24 & 0.31 \\
\hline С5-C4-C9-C8 & 0.16 \\
\hline С5-C4-C9-H24 & -179.67 \\
\hline C3-C4-C5-C6 & 179.85 \\
\hline C3-C4-C5-H21 & -0.04 \\
\hline C9-C4-C5-C6 & -0.18 \\
\hline C9-C4-C5-H21 & 179.94 \\
\hline C2-C3-C4-C5 & -177.68 \\
\hline C2-C3-C4-C9 & 2.35 \\
\hline $\mathrm{H} 20-\mathrm{C} 3-\mathrm{C} 4-\mathrm{C} 5$ & 1.97 \\
\hline H20-C3-C4-C9 & -178.00 \\
\hline C1-C2-C3-C4 & 179.64 \\
\hline C1-C2-C3-H20 & 0.00 \\
\hline H19-C2-C3-C4 & 0.49 \\
\hline $\mathrm{H} 19-\mathrm{C} 2-\mathrm{C} 3-\mathrm{H} 20$ & -179.15 \\
\hline C2-C1-N16-017 & -179.62 \\
\hline C10-C1-N16-017 & 0.47 \\
\hline C2-C1-C10-C11 & -106.31 \\
\hline C2-C1-C10-C15 & 73.39 \\
\hline N16-C1-C10-C11 & 73.60 \\
\hline N16-C1-C10-C15 & -106.70 \\
\hline C10-C1-C2-C3 & 3.14 \\
\hline C10-C1-C2-H19 & -177.66 \\
\hline N16-C1-C2-C3 & -176.78 \\
\hline N16-C1-C2-H19 & 2.42 \\
\hline
\end{tabular}

Table B.4. Calculated Bond Lengths, Bond Angels and Dihedral Angles for Compound $(E)-6 \mathrm{a}$

\begin{tabular}{cccccc}
\hline Atoms & Bond Length & Atoms & Bond Angle & Atoms & Dihedral Angle \\
\hline H43-C24 & 1.085 & H43-C24-C19 & 119.484 & C23-C24-C19-C20 & 0.17 \\
H42-C23 & 1.084 & H43-C24-C23 & 119.75 & C23-C24-C19-C18 & -178.867 \\
H41-C22 & 1.084 & C19-C24-C23 & 120.766 & H43-C24-C19-C20 & -179.712 \\
H40-C21 & 1.084 & H42-C23-C24 & 119.944 & H43-C24-C19-C18 & 1.251 \\
H39-C20 & 1.083 & H42-C23-C22 & 120.117 & C19-C24-C23-C22 & 0.006 \\
H38-C18 & 1.091 & C24-C23-C22 & 119.939 & C19-C24-C23-H42 & -179.781 \\
H37-C18 & 1.091 & H41-C22-C23 & 120.113 & H43-C24-C23-C22 & 179.888 \\
H36-C16 & 1.083 & H41-C22-C21 & 120.121 & H43-C24-C23-H42 & 0.101 \\
H35-C15 & 1.082 & C23-C22-C21 & 119.765 & C24-C23-C22-C21 & -0.098 \\
H34-C13 & 1.082 & H40-C21-C22 & 120.034 & C24-C23-C22-H41 & -179.852 \\
H33-C12 & 1.084 & H40-C21-C20 & 119.829 & H42-C23-C22-C21 & 179.688 \\
H32-C10 & 1.086 & C22-C21-C20 & 120.138 & H42-C23-C22-H41 & -0.065 \\
H31-C9 & 1.082 & H39-C20-C21 & 120.068 & C23-C22-C21-C20 & 0.011 \\
H30-C8 & 1.084 & H39-C20-C19 & 119.374 & C23-C22-C21-H40 & -179.841 \\
H29-C7 & 1.084 & C21-C20-C19 & 120.555 & H41-C22-C21-C20 & 179.765 \\
H28-C6 & 1.084 & C18-C19-C24 & 120.376 & H41-C22-C21-H40 & -0.087 \\
H27-C5 & 1.083 & C18-C19-C20 & 120.78 & C22-C21-C20-C19 & 0.169
\end{tabular}


T. Erdoğan / The First Synthesis of Some Novel 4-Chloro Chalcone Based Oxime Ethers: An Experimental and Computational Study.

\begin{tabular}{|c|c|c|c|}
\hline H26-C1 & 1.082 & C24-C19-C20 & 118.837 \\
\hline $\mathrm{Cl} 25-\mathrm{C} 14$ & 1.755 & Н37-С18-Н38 & 109.155 \\
\hline C24-C19 & 1.396 & Н37-С18-017 & 108.233 \\
\hline C24-C23 & 1.391 & Н37-C18-C19 & 111.407 \\
\hline C23-C22 & 1.391 & Н38-С18-017 & 103.91 \\
\hline C22-C21 & 1.392 & Н38-C18-С19 & 110.768 \\
\hline C21-C20 & 1.391 & 017-C18-C19 & 113.048 \\
\hline C20-C19 & 1.396 & N3-017-C18 & 109.462 \\
\hline C19-C18 & 1.507 & H36-C16-C11 & 120.135 \\
\hline C18-017 & 1.441 & Н36-C16-С15 & 118.572 \\
\hline 017-N3 & 1.396 & C11-C16-C15 & 121.293 \\
\hline C16-C11 & 1.404 & Н35-C15-C16 & 120.585 \\
\hline C16-C15 & 1.385 & H35-C15-C14 & 119.949 \\
\hline C15-C14 & 1.391 & C16-C15-C14 & 119.466 \\
\hline C14-C13 & 1.387 & Cl25-C14-C15 & 119.479 \\
\hline C13-C12 & 1.388 & Cl25-C14-C13 & 119.672 \\
\hline C12-C11 & 1.402 & C15-C14-C13 & 120.85 \\
\hline C11-C10 & 1.462 & Н34-C13-С14 & 120.213 \\
\hline C10-C1 & 1.344 & Н34-C13-C12 & 120.754 \\
\hline С9-С8 & 1.390 & C14-C13-C12 & 119.033 \\
\hline C9-C4 & 1.398 & Н33-С12-С13 & 119.053 \\
\hline C8-C7 & 1.391 & H33-C12-C11 & 119.231 \\
\hline C7-C6 & 1.392 & C13-C12-C11 & 121.716 \\
\hline C6-C5 & 1.390 & C10-C11-C16 & 123.553 \\
\hline C5-C4 & 1.399 & C10-C11-C12 & 118.805 \\
\hline $\mathrm{C} 4-\mathrm{C} 2$ & 1.490 & C16-C11-C12 & 117.642 \\
\hline $\mathrm{N} 3-\mathrm{C} 2$ & 1.292 & H32-C10-C1 & 118.457 \\
\hline \multirow[t]{27}{*}{$\mathrm{C} 2-\mathrm{C} 1$} & 1.460 & H32-C10-C11 & 114.726 \\
\hline & & C1-C10-C11 & 126.807 \\
\hline & & Н31-С9-С8 & 120.383 \\
\hline & & H31-C9-C4 & 119.018 \\
\hline & & C8-C9-C4 & 120.599 \\
\hline & & Н30-С8-С9 & 119.723 \\
\hline & & Н30-С8-C7 & 120.076 \\
\hline & & С9-С8-C7 & 120.2 \\
\hline & & Н29-С7-C8 & 120.203 \\
\hline & & H29-C7-C6 & 120.154 \\
\hline & & C8-C7-C6 & 119.643 \\
\hline & & H28-C6-C7 & 120.096 \\
\hline & & H28-C6-C5 & 119.693 \\
\hline & & C7-C6-C5 & 120.21 \\
\hline & & H27-C5-C6 & 119.787 \\
\hline & & $\mathrm{H} 27-\mathrm{C} 5-\mathrm{C} 4$ & 119.646 \\
\hline & & С6-C5-C4 & 120.556 \\
\hline & & $\mathrm{C} 2-\mathrm{C} 4-\mathrm{C} 9$ & 120.146 \\
\hline & & $\mathrm{C} 2-\mathrm{C} 4-\mathrm{C} 5$ & 121.04 \\
\hline & & C9-C4-C5 & 118.79 \\
\hline & & C2-N3-017 & 113.171 \\
\hline & & C1-C2-N3 & 123.597 \\
\hline & & $\mathrm{C} 1-\mathrm{C} 2-\mathrm{C} 4$ & 122.058 \\
\hline & & N3-C2-C4 & 114.346 \\
\hline & & H26-C1-C2 & 114.822 \\
\hline & & H26-C1-C10 & 120.533 \\
\hline & & C2-C1-C10 & 124.599 \\
\hline
\end{tabular}

\begin{tabular}{|c|c|}
\hline С22-С21-С20-Н39 & 179.585 \\
\hline H40-C21-C20-C19 & -179.979 \\
\hline H40-C21-C20-H39 & -0.562 \\
\hline C21-C20-C19-C24 & -0.257 \\
\hline С21-С20-С19-С18 & 178.776 \\
\hline Н39-C20-C19-С24 & -179.678 \\
\hline Н39-С20-С19-С18 & -0.645 \\
\hline С20-C19-C18-017 & -88.957 \\
\hline С20-С19-С18-Н38 & 154.892 \\
\hline С20-C19-С18-Н37 & 33.184 \\
\hline С24-С19-С18-017 & 90.061 \\
\hline С24-С19-С18-Н38 & -26.09 \\
\hline C24-C19-C18-H37 & -147.798 \\
\hline C19-C18-017-N3 & 81.315 \\
\hline H38-C18-017-N3 & -158.529 \\
\hline H37-C18-017-N3 & -42.586 \\
\hline C18-017-N3-C2 & -170.543 \\
\hline C15-C16-C11-C12 & 0.245 \\
\hline C15-C16-C11-C10 & -179.86 \\
\hline H36-C16-C11-C12 & -179.465 \\
\hline H36-C16-C11-C10 & 0.43 \\
\hline C11-C16-C15-C14 & -0.035 \\
\hline C11-C16-C15-H35 & -179.922 \\
\hline H36-C16-C15-C14 & 179.68 \\
\hline Н36-C16-C15-H35 & -0.207 \\
\hline C16-C15-C14-C13 & -0.114 \\
\hline C16-C15-C14-Cl25 & -179.988 \\
\hline Н35-C15-C14-C13 & 179.773 \\
\hline H35-C15-C14-Cl25 & -0.101 \\
\hline C15-C14-C13-C12 & 0.043 \\
\hline C15-C14-C13-Н34 & -179.903 \\
\hline $\mathrm{Cl} 25-\mathrm{C} 14-\mathrm{C} 13-\mathrm{C} 12$ & 179.917 \\
\hline $\mathrm{Cl} 25-\mathrm{C} 14-\mathrm{C} 13-\mathrm{H} 34$ & -0.03 \\
\hline C14-C13-C12-C11 & 0.179 \\
\hline C14-C13-C12-H33 & 179.996 \\
\hline H34-C13-C12-C11 & -179.874 \\
\hline H34-C13-C12-H33 & -0.058 \\
\hline C13-C12-C11-C16 & -0.319 \\
\hline C13-C12-C11-C10 & 179.781 \\
\hline H33-C12-C11-C16 & 179.865 \\
\hline H33-C12-C11-C10 & -0.035 \\
\hline C12-C11-C10-C1 & -175.145 \\
\hline С12-C11-C10-Н32 & 3.698 \\
\hline C16-C11-C10-C1 & 4.961 \\
\hline С16-C11-C10-H32 & -176.196 \\
\hline C11-C10-C1-C2 & 179.104 \\
\hline C11-C10-C1-H26 & 1.724 \\
\hline H32-C10-C1-C2 & 0.299 \\
\hline $\mathrm{H} 32-\mathrm{C} 10-\mathrm{C} 1-\mathrm{H} 26$ & -177.081 \\
\hline C4-C9-C8-C7 & 0.195 \\
\hline С4-С9-С8-H30 & -179.663 \\
\hline H31-С9-С8-C7 & -179.835 \\
\hline Н31-C9-C8-H30 & 0.306 \\
\hline C8-C9-C4-C5 & -0.04 \\
\hline C8-C9-C4-C2 & -178.286 \\
\hline H31-C9-C4-C5 & 179.99 \\
\hline H31-C9-C4-C2 & 1.744 \\
\hline С9-C8-C7-C6 & -0.045 \\
\hline С9-C8-C7-H29 & 179.963 \\
\hline H30-C8-C7-C6 & 179.813 \\
\hline H30-C8-C7-H29 & -0.179 \\
\hline C8-C7-C6-C5 & -0.261 \\
\hline С8-C7-C6-H28 & 179.372 \\
\hline $\mathrm{H} 29-\mathrm{C} 7-\mathrm{C} 6-\mathrm{C} 5$ & 179.732 \\
\hline H29-C7-C6-H28 & -0.635 \\
\hline C7-C6-C5-C4 & 0.419 \\
\hline C7-C6-C5-H27 & 179.249 \\
\hline $\mathrm{H} 28-\mathrm{C} 6-\mathrm{C} 5-\mathrm{C} 4$ & -179.216 \\
\hline H28-C6-C5-H27 & -0.385 \\
\hline C6-C5-C4-C9 & -0.266 \\
\hline C6-C5-C4-C2 & 177.964 \\
\hline $\mathrm{H} 27-\mathrm{C} 5-\mathrm{C} 4-\mathrm{C} 9$ & -179.098 \\
\hline $\mathrm{H} 27-\mathrm{C} 5-\mathrm{C} 4-\mathrm{C} 2$ & -0.869 \\
\hline C5-C4-C2-N3 & -130.991 \\
\hline C5-C4-C2-C1 & 49.019 \\
\hline C9-C4-C2-N3 & 47.215 \\
\hline
\end{tabular}


C9-C4-C2-C1

017-N3-C2-C4

017-N3-C2-C1

C4-C2-C1-C10

C4-C2-C1-H26

N3-C2-C1-C10

N3-C2-C1-H26
$-132.775$

$-176.022$

3.967

18.245

$-164.241$

$-161.743$

15.771

Table B.5. Calculated Bond Lengths, Bond Angels and Dihedral Angles for Compound (Z)-6a

\begin{tabular}{|c|c|c|c|c|c|}
\hline Atoms & Bond Length & Atoms & Bond Angle & Atoms & Dihedral Angle \\
\hline H43-C24 & 1.083 & H43-C24-C14 & 119.371 & C23-C24-C14-C20 & 0.34 \\
\hline H42-C23 & 1.084 & H43-C24-C23 & 120.051 & С23-С24-C14-C13 & -178.423 \\
\hline H41-C22 & 1.084 & C14-C24-C23 & 120.576 & H43-C24-C14-C20 & 179.762 \\
\hline $\mathrm{H} 40-\mathrm{C} 21$ & 1.084 & $\mathrm{H} 42-\mathrm{C} 23-\mathrm{C} 24$ & 119.835 & H43-C24-C14-C13 & 0.999 \\
\hline H39-С20 & 1.085 & $\mathrm{H} 42-\mathrm{C} 23-\mathrm{C} 22$ & 120.032 & C14-C24-C23-C22 & -0.216 \\
\hline H38-C19 & 1.083 & C24-C23-C22 & 120.133 & C14-C24-C23-H42 & 179.967 \\
\hline H37-C18 & 1.082 & H41-C22-C23 & 120.131 & H43-C24-C23-C22 & -179.633 \\
\hline H36-C16 & 1.082 & H41-C22-C21 & 120.116 & Н43-С24-C23-H42 & 0.549 \\
\hline H35-C15 & 1.084 & C23-C22-C21 & 119.753 & С24-C23-C22-C21 & -0.029 \\
\hline H34-C13 & 1.092 & H40-C21-C22 & 120.109 & C24-C23-C22-H41 & -179.765 \\
\hline H33-C13 & 1.091 & $\mathrm{H} 40-\mathrm{C} 21-\mathrm{C} 20$ & 119.929 & H42-C23-C22-C21 & 179.789 \\
\hline H32-C10 & 1.085 & C22-C21-C20 & 119.961 & H42-C23-C22-H41 & 0.052 \\
\hline H31-C8 & 1.085 & H39-С20-C21 & 119.76 & С23-С22-C21-C20 & 0.142 \\
\hline H30-C6 & 1.081 & H39-C20-C14 & 119.486 & C23-C22-C21-H40 & -179.645 \\
\hline $\mathrm{H} 29-\mathrm{C} 4$ & 1.084 & C21-C20-C14 & 120.754 & H41-C22-C21-C20 & 179.879 \\
\hline H28-C3 & 1.084 & H38-C19-C11 & 120.084 & H41-C22-C21-H40 & 0.091 \\
\hline $\mathrm{H} 27-\mathrm{C} 2$ & 1.084 & H38-C19-C18 & 118.559 & C22-C21-C20-C14 & -0.013 \\
\hline H26-C1 & 1.084 & C11-C19-C18 & 121.352 & С22-С21-С20-Н39 & -179.917 \\
\hline $\mathrm{Cl} 25-\mathrm{C} 17$ & 1.756 & H37-C18-C19 & 120.605 & H40-C21-C20-C14 & 179.775 \\
\hline C24-C14 & 1.396 & H37-C18-C17 & 119.953 & H40-C21-C20-H39 & -0.129 \\
\hline C24-C23 & 1.390 & C19-C18-C17 & 119.44 & C21-C20-C14-C24 & -0.226 \\
\hline C23-C22 & 1.392 & $\mathrm{Cl} 25-\mathrm{C} 17-\mathrm{C} 18$ & 119.49 & C21-C20-C14-C13 & 178.543 \\
\hline C22-C21 & 1.391 & $\mathrm{Cl} 25-\mathrm{C} 17-\mathrm{C} 16$ & 119.678 & Н39-С20-С14-С24 & 179.678 \\
\hline C21-C20 & 1.391 & C18-C17-C16 & 120.831 & H39-С20-C14-C13 & -1.553 \\
\hline C20-C14 & 1.396 & Н36-C16-C17 & 120.197 & C18-C19-C11-C15 & -0.796 \\
\hline C19-C11 & 1.404 & H36-C16-C15 & 120.739 & C18-C19-C11-C10 & 179.284 \\
\hline C19-C18 & 1.385 & C17-C16-C15 & 119.064 & H38-C19-C11-C15 & 178.431 \\
\hline C18-C17 & 1.391 & H35-C15-C16 & 119.084 & H38-C19-C11-C10 & -1.489 \\
\hline C17-C16 & 1.387 & H35-C15-C11 & 119.189 & C11-C19-C18-C17 & 0.319 \\
\hline C16-C15 & 1.388 & C16-C15-C11 & 121.727 & C11-C19-C18-H37 & 179.824 \\
\hline C15-C11 & 1.402 & C13-C14-C24 & 120.815 & H38-C19-C18-C17 & -178.92 \\
\hline C14-C13 & 1.507 & C13-C14-C20 & 120.351 & Н38-C19-С18-Н37 & 0.586 \\
\hline C13-012 & 1.441 & C24-C14-C20 & 118.822 & C19-C18-C17-C16 & 0.229 \\
\hline 012-N9 & 1.393 & H33-C13-H34 & 109.174 & C19-C18-C17-Cl25 & 179.837 \\
\hline C11-C10 & 1.462 & H33-C13-012 & 103.964 & H37-C18-C17-C16 & -179.28 \\
\hline C10-C8 & 1.342 & H33-C13-C14 & 110.748 & H37-C18-C17-Cl25 & 0.328 \\
\hline N9-C7 & 1.289 & Н34-C13-012 & 108.332 & C18-C17-C16-C15 & -0.265 \\
\hline C8-C7 & 1.471 & H34-C13-C14 & 111.501 & C18-C17-C16-H36 & 179.669 \\
\hline $\mathrm{C} 7-\mathrm{C} 5$ & 1.490 & 012-C13-C14 & 112.803 & Cl25-C17-C16-C15 & -179.873 \\
\hline C6-C1 & 1.389 & N9-012-C13 & 109.551 & Cl25-C17-C16-H36 & 0.061 \\
\hline C6-C5 & 1.399 & C10-C11-C19 & 123.525 & C17-C16-C15-C11 & -0.245 \\
\hline C5-C4 & 1.398 & C10-C11-C15 & 118.895 & C17-C16-C15-H35 & -179.95 \\
\hline C4-C3 & 1.390 & C19-C11-C15 & 117.58 & H36-C16-C15-C11 & 179.822 \\
\hline C3-C2 & 1.390 & H32-C10-C8 & 117.505 & Н36-C16-C15-H35 & 0.116 \\
\hline \multirow[t]{21}{*}{$\mathrm{C} 2-\mathrm{C} 1$} & 1.392 & H32-C10-C11 & 115.58 & C16-C15-C11-C19 & 0.761 \\
\hline & & C8-C10-C11 & 126.909 & C16-C15-C11-C10 & -179.315 \\
\hline & & C7-N9-012 & 113.864 & H35-C15-C11-C19 & -179.534 \\
\hline & & H31-C8-C7 & 114.984 & H35-C15-C11-C10 & 0.39 \\
\hline & & H31-C8-C10 & 120.385 & С20-C14-C13-012 & -91.121 \\
\hline & & C7-C8-C10 & 124.617 & C20-C14-C13-H34 & 146.716 \\
\hline & & C5-C7-C8 & 117.55 & С20-C14-C13-Н33 & 24.932 \\
\hline & & C5-C7-N9 & 126.291 & C24-C14-C13-012 & 87.623 \\
\hline & & C8-C7-N9 & 116.159 & С24-C14-C13-H34 & -34.539 \\
\hline & & H30-C6-C1 & 120.005 & C24-C14-C13-H33 & -156.324 \\
\hline & & H30-C6-C5 & 119.593 & C14-C13-012-N9 & -82.957 \\
\hline & & C1-C6-C5 & 120.401 & H34-C13-012-N9 & 40.971 \\
\hline & & C7-C5-C6 & 121.825 & H33-C13-012-N9 & 157.007 \\
\hline & & C7-C5-C4 & 119.365 & C13-012-N9-C7 & 172.551 \\
\hline & & C6-C5-C4 & 118.762 & C15-C11-C10-C8 & 169.754 \\
\hline & & $\mathrm{H} 29-\mathrm{C} 4-\mathrm{C} 5$ & 119.539 & C15-C11-C10-H32 & -9.335 \\
\hline & & H29-C4-C3 & 119.704 & C19-C11-C10-C8 & -10.327 \\
\hline & & $\mathrm{C} 5-\mathrm{C} 4-\mathrm{C} 3$ & 120.753 & C19-C11-C10-H32 & 170.584 \\
\hline & & $\mathrm{H} 28-\mathrm{C} 3-\mathrm{C} 4$ & 119.778 & C11-C10-C8-C7 & 178.179 \\
\hline & & H28-C3-C2 & 120.203 & C11-C10-C8-H31 & -3.238 \\
\hline & & $\mathrm{C} 4-\mathrm{C} 3-\mathrm{C} 2$ & 120.018 & H32-C10-C8-C7 & -2.748 \\
\hline
\end{tabular}




\begin{tabular}{|c|c|c|c|}
\hline H27-C2-C3 & 120.18 & H32-C10-С8-H31 & 175.836 \\
\hline H27-C2-C1 & 120.161 & 012-N9-C7-C8 & 174.362 \\
\hline C3-C2-C1 & 119.658 & 012-N9-C7-C5 & -5.809 \\
\hline H26-C1-C6 & 119.6 & C10-C8-C7-N9 & -28.054 \\
\hline H26-C1-C2 & 120.003 & C10-C8-C7-C5 & 152.101 \\
\hline C6-C1-C2 & 120.397 & H31-C8-C7-N9 & 153.295 \\
\hline & & H31-C8-C7-C5 & -26.55 \\
\hline & & N9-C7-C5-C4 & 135.751 \\
\hline & & N9-C7-C5-C6 & -46.807 \\
\hline & & C8-C7-C5-C4 & -44.421 \\
\hline & & C8-C7-C5-C6 & 133.02 \\
\hline & & C5-C6-C1-C2 & -0.788 \\
\hline & & С5-C6-C1-H26 & 179.352 \\
\hline & & H30-C6-C1-C2 & 179.493 \\
\hline & & H30-C6-C1-H26 & -0.367 \\
\hline & & C1-C6-C5-C4 & 0.065 \\
\hline & & C1-C6-C5-C7 & -177.392 \\
\hline & & H30-C6-C5-C4 & 179.785 \\
\hline & & H30-C6-C5-C7 & 2.329 \\
\hline & & C6-C5-C4-C3 & 0.853 \\
\hline & & C6-C5-C4-H29 & -179.872 \\
\hline & & C7-C5-C4-C3 & 178.373 \\
\hline & & C7-C5-C4-H29 & -2.352 \\
\hline & & C5-C4-C3-C2 & -1.05 \\
\hline & & C5-C4-C3-H28 & 179.188 \\
\hline & & H29-C4-C3-C2 & 179.676 \\
\hline & & H29-C4-C3-H28 & -0.086 \\
\hline & & C4-C3-C2-C1 & 0.318 \\
\hline & & C4-C3-C2-H27 & -179.52 \\
\hline & & H28-C3-C2-C1 & -179.92 \\
\hline & & H28-C3-C2-H27 & 0.241 \\
\hline & & C3-C2-C1-C6 & 0.595 \\
\hline & & C3-C2-C1-H26 & -179.545 \\
\hline & & H27-C2-C1-C6 & -179.566 \\
\hline & & H27-C2-C1-H26 & 0.294 \\
\hline
\end{tabular}

